EFEITO DA SUBSTITUIÇ.̃̃o PARCIAL DA' PROTEI NA DO FARELO

DE ALGODã POR UREIA SOBRE ALGUNS PARAMETROS

FERMENTATI YOS EM LI QUIDO RUMINAL DE

BUBALINOS EM CRESCIMENTO

\title{
CLAUDINEI PARRE
}

Engenheiro Agrônomo

Aprovado em: 12 de maio de 1989

Comissão Julgadora:

Prof. Dr. Antonio Carlos Silveira - FMVZ UNESP

Prof. Dr. Wilson Roberto Soares Mattos - ESALQ/USP

Prof. Dr. Raul Machado Neto - ESALQ/USP

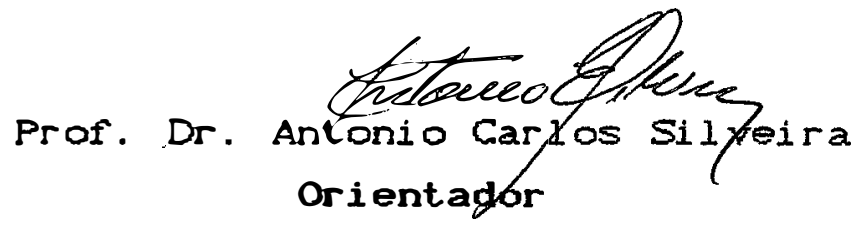


Parre, claudinei.

Efeito da substituica da proteina do farelo de algodao por ureia sobro alguns parametros fermentativos em liquido ruminal de bubalinos em oresoimento. Piracicaba.1980. $75 \mathrm{p}$.

Diss. (Mestre) - ESALQ

Bibliografia.

1. Bubalinos - Grescimento 2 . BubalinosNutricao 3. Proteina do farelo de algodoo na nutricao animal 4. Rumon - Paramotros fermentativos s. Ureia na nutricao animal I. Escola superior de Agricultura luiz de Queiroz, Piracicaba 
Aos meus pais Brasilio Parre

- Arlete de Oliveira Parré por terem me dado a vida, educação e amor.

OFEREGO

A Maria Fernanda Martins, com meu profundo carinho. 


\section{AGRADECI MENTOS}

Ao Prof. Dr. Antonio Carlos Silveira pela orientação, incentivo e principal mente amizade.

Aos colegas, Luiz Roberto Furnan, Mario De Beni Arrigoni, Luiz Edivaldo Pezzato, Nabor Veiga, Otávia Elisa Nogueira Mendes Lavezzo e Paulo Roberto Curi pela col aboração.

Ao Dino Potiens Filho, Antonio Garcia Monteiro, Jose Luiz Barbosa de Souza, Eliane Rodrigues, Arlindo Braga, Celso Paulo Martin e Jaime Figueira, pela col aboração.

Ao Departamento de Produção e Exploração Animal e a Faculdade de Medicina Veterinaria e Zootecnia, UNESP, Campus de Botucatu, pelas facilidades concedidas.

A Coordenação de Aperfeiçoamento de Pessoal de Ensino Superior CCAPESO, pela concessão de bolsa de estudo.

Ãqueles que, direta ou indiretamente, colaboraram para a realização deste trabal ho. 
LISTA DE FIGURAS....................... iv

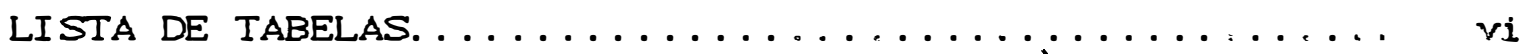

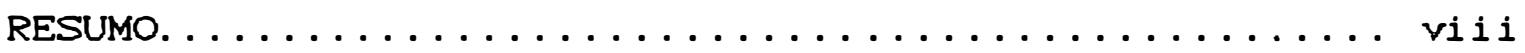

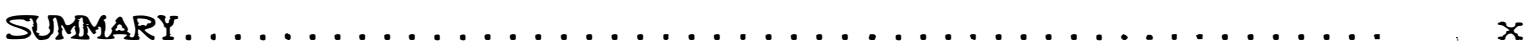

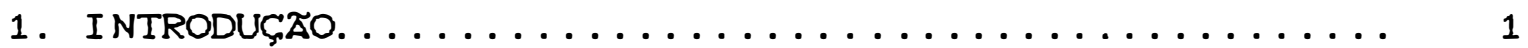

2. REVISATO DE LITERATURA. .................... 4

2.1. Utilização da uréia pelos microrganismos

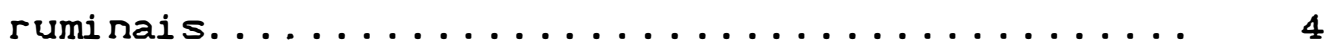

2. 2. Influencia da ureia em alguns parâmetros fermentativos do 1 iquido ruminal............ 9

2. 3. Tempo de amostragem................... 20

2. 4. Métodos de coleta e animais utilizados....... 21

3. MATERIAL E METODOS. ....................... 24

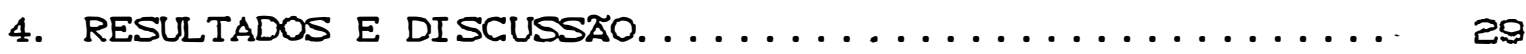

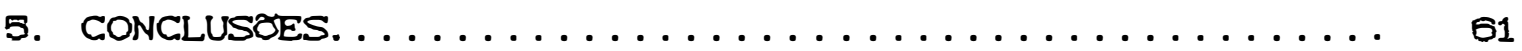

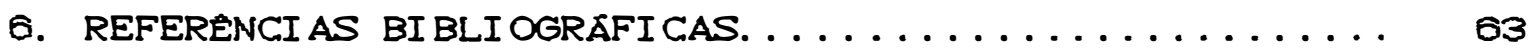




\section{LISTAS DE FIGURAS}

Figura

Página

1. Niveis médios de nitrogénio amoniacal em 11 quido ruminal de butialinos, sob duas difias e em quatro tempos experimentais...............

2. Niveis médios de nitrogénio amoniacal em liquido ruminal de bubalinos, sob duas dietas e

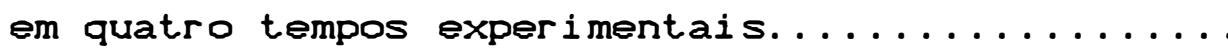

3. Niveis médios de $\mathrm{pH}$ em liquido ruminal de bubalinos, sob duas dietas e em quatro tempos experimentais.....................

4. Níveis médios de $\mathrm{pH}$ em liquido ruminal de bubalinos, sob duas dietas e em quatro tempos experimentais....................

5. Niveis médios de ácido graxos volateis totais em liquido ruminal de bubalinos, sob duas dietas e em quatro tempos experimentais...

6. Niveis médios de ácido graxos volateis totais em liquido ruminal de bubalinos, sob duas dietas e em quatro tempos experimentais.........

7. Níveis médios de ácido acético em liquido ruminal de bubalinos, sob duas dietas e em quatro tempos experimentais................

8. Niveis médios de ácido acético em liquido ruminal de bubalinos, sob duas dietas e em quatro tempos experimentais................ 
9. Niveis médios de ácido propionico em liquido ruminal de bubalinos, sob duas dietas e em quatro tempos experimentais............... 51

10. Niveis medios de ácido propionico em liquido ruminal de bubalinos, sob duas dietas e em quatro tempos experimentais................ 52

11. Niveis médios de acido butirico em liquido ruminal de bubalinos, sob duas dietas e em quatro tempos experimentais................

12. Niveis medios de acido butirico em liquido ruminal de bubalinos, sob duas dietas e em

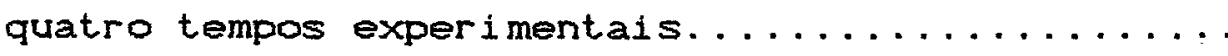




\section{LISTA DE TABELAS}

Tabela

Pagina

1. Composição centesimal das dietas experimentais

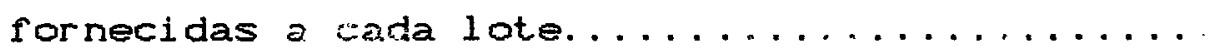

2. Valores médios da concentraçăo de nitrogenio amoniacal (mg/dl) no liquido ruminal de bubalinos, sob duas dietas experimentais, em diferentes tempos......................

3. Resumo da análise de variancia do perfil das medias de concentração de nitrogenio amoniacal, referentes a Tabela $2 \ldots . . . . . . . .$.

4. Valores médios de $\mathrm{pH}$ no 1 iquido ruminal de bubalinos, sob duas dietas experimentais, em diferentes tempos.......................

5. Resumo da análise de variancia do perfil das medias de $\mathrm{pH}$, referentes a Tabela $4 \ldots \ldots \ldots \ldots \ldots$

6. Valores médios da concentraça de acidos graxos volateis totais $\mathrm{CmM}$ no 1 iquido ruminal de bubalinos, sob duas dietas experimentais,

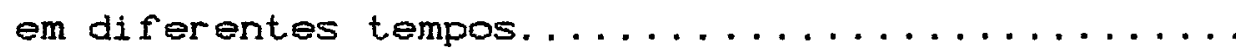

7. Resumo da análise de variancia do perfil da concentração de acidos graxos volateis totais CmM referentes a Tabela

8. Valores médios da concentração de ácido acético $\mathrm{CmM}$ no 1 iquido ruminal de bubalinos, sob duas dietas experimentais,em diferentes

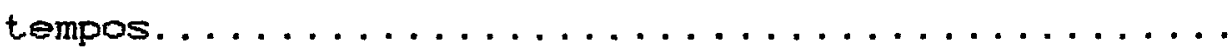


9. Resumo da análise de variancia do perfil da concentração de acido acetico cmM, referente

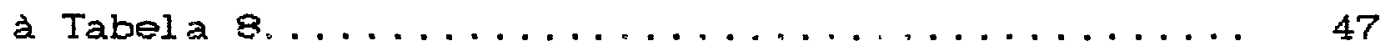

10. Valores medios da concentração de ácido propionico $\mathrm{CmM}$ no 11 quido ruminal de bubalinos, sob duas dietas experimentais, em diferentes tempos......................

11. Resumo da análise de variancia do perfil da concentraça de ácido propionico cmM

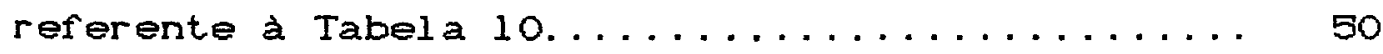

12. Valores medios de concentração de ácido butirico $\mathrm{CmM}$ no liquido ruminal de bubalinos, sob duas dietas experimentais,em diferentes

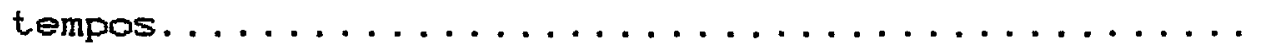

13. Resumo da análise de variancia do perfil da concentração de ácido butfrico $\mathrm{cmM}$, referentes a Tabela $12 \ldots \ldots \ldots \ldots \ldots \ldots \ldots \ldots$ 
EFEITO DA SUBSTITUI ÇÃO PARCIAL DA PROTEINA DO FARELO

DE ALGODAOO POR UREIA SOBRE ALGUNS PARAMETROS

FERMENTATIVOS EM LI QUTDO RUMTNAL DE

BUBALINOS EM CRESCIMENTO

Autor: GLAUDINEI PARRE

Orientador: PROF. DR. ANTONIO CARLOS SILVEIRA

RESUMO

Com o objetivo de estudar o efeito da substituiça parcial da proteina do farelo de algodão por ureia sobre os parametros fermentativos ruminais, 20 búfalos machos em crescimento, com 12 meses de idade e $218 \pm 18 \mathrm{~kg}$ de peso vivo medio foram uniformemente distribuidos em dois tratamentos, que constaram de duas dietas distintas: Dieta A: a fonte de proteina era o farelo de algodão e Dieta B: o farelo de algodão foi parcialmente substituido pela ureia, ambas com niveis de $16,5 \%$ de $\mathrm{PB}$ e $68 \%$ de NDT. Após 28 dias de perído de adaptaça, o liquido ruminal foi amostrado por meio de sonda esofagiana, nos tempos $0,1,3$ e 6 horas após a ingestão de alimentos. No 11 quido ruminal amostrado, foram mensurados os valores de $\mathrm{pH}$, nitrogenio amoniacal $\mathrm{Cmg} / \mathrm{dl}$, N-NHa) e ácidos graxos voláteis (mM, AGV.

Os resultados mostraram valores de $\mathrm{pH}$ superiores $(P<0,05\rangle$, em todos os tempos de amostragen para a dieta $A(7,35 ; 7,14 ; 6,79$ 0,88) em relaçăo à dieta $B$ 
$(6,79 ; 6,61 ; 6,29$ 6,80). As concentraç8es mais elevadas de N-NHa foram registradas uma hora após a ingestã de alimentos para a dieta $\mathrm{B}(9,36 ; 34,23 ; 18,44$ e $6,11 \mathrm{mg} / \mathrm{dl})$ e entre 1 a 3 horas para a dieta $A(14,61 ; 23,10 ; 18,17$; 9,13 mg/dl $/$, indicando uma rápida degradação da uréia no rumen.

Foram observadas diferenças estatisticamente significativas $(P<0,05)$ entre as concentraç̧es de AGV no 1 iquido ruminal, onde a dieta composta somente por farelo de algodå apresentou maiores teores de ácidos graxos volateis totais, acido acético, acido propionico e ácido butirico, nos tempos $0,1,3$ e horas apos a ingestao de alimentos.

Ambas as dietas provavelmente possibilitaram condiç̧es adequadas para o desenvolvimento dos microrganismos ruminais. A dieta com farelo de algodão apresentou padräes de fermentação superiores em relaçăo as concentraç̧es de AGV, caracterizando uma atividade microbiana mais constante no rúmen. 


\section{EFFECT OF PARTIAL SUBSTITUTION OF COTTONSEED MEAL PROTEIN BY. UREA ON SOME FERMENTATION PARAMETERS IN RUMTNAL LIQUOR OF GROWING BUFFALOES}

Author: CLAUDINEI PARRE Adviser: PROF. DR. ANTONIO GARLOS SILVEIRA

\section{SUMMARY}

In order to study the effect of partial substitution of cottonseed meal protein by urea on some fermentation ruminal parameters, 20 male growing buffaloes, 12 months of age and $218 \pm 18 \mathrm{~kg}$ of $1 \mathrm{ive}$ weight, were provided with two diets: a) protein from cottonseed meal and b) protein from cottonseed meal was replaced by $1 \%$ of urea, both with $16,5 \%$ of crude protein and $68 \%$ of TDN. After an adaptation period of 28 days, the ruminal liquor was collected by esophagian tube at $0,1,3$ and 6 hours after feeding. The following parameters were measured: pH, amonia nitrogen concentration $(\mathrm{mg} / \mathrm{dl}, \mathrm{N}-\mathrm{NH} 3 \mathrm{~S}$ and volatile fatty acids levels CVFA, mM.

The results showed higher $\mathrm{pH}$ values $(P<.05)$ at all sampling times for the diet with urea $67.35 ; 7.14 ; 6,79$ and 6.68) compared to the diet with cottonseed meal (6.79; $6.61 ; 0.29$ and 6.303. The peaks of $\mathrm{N}-\mathrm{NH3}$ concentration occurred I hour after feed intake for the diet with urea 
(9.36; 34.23; 18.44 and $6.11 \mathrm{mg} / \mathrm{dl}$ and withim $1-3$ hours for the diet with cottonseed meal only $614.61 ; 23.10 ; 18.18$ and $9.13 \mathrm{mg} / \mathrm{dl}$, indicating a fast urea degradation in the rumen.

There were differences (P<. OS) between the VFA concentration in the ruminal liquor, with the cottonseed diet showing higher levels of total VFA and acetic, propionic and butyric acids at $0,1,3$ and 6 hours after feeding, when compared with the diet with urea.

Both diets probably provided suitable conditions for the ruminal microorganisms development. The diet with cottonseed meal only, showed higher fermentation patterns mainly those related to the VFA concentrations, indicating a normal microorganisms activity in the rumen. 
1. INTRODUÇÃO

Recentes estudos publicados pela FAO mostraram que na maior parte dos paises em desenvolvimento, o consumo de carne e leite vem aumentando a uma razão de 6 a $7 \%$ ao ano e se preve que esta elevada taxa continuara até o ano 2000. Para tornar isto possivel, a produçăo de alimentos de origem animal deverá aumentar rapidamente significando que, ao final do século, a produção animal combinada de carne, $\Theta$ leite ovos deverá ser igual aproximadamente a 2,4 vezes a dos niveis atuais.

Afim de suprir esta impressionante demanda, torna-se necessário rever os sistemas de producăo zootécnica, buscando-se maior produção por animal e maior produção por área.

Entretanto, para atingir tais objetivos havera necessidade de avaliar os múltiplos recursos ainda disponiveis na natureza, que permitam a obtenção e 
utilização de novas fontes de alimento para o rebanho, como - o caso da ureía.

Apesar de ter sido sintetizada pela primeira vez no século passado, a uréia começou a ser incluida em raços para animais apenas no final do mesmo, despertando maior interesse há aproximadamente 50 anos, quando os processos ligados a estreita simbiose entre ruminantes e os microrganismos do rumem, passaram a ser melhor conhecidos. Os resultados dos estudos a respeito comecaram a ser então utilizados para fins práticos de arraçoamento, visando substituição parcial das protelnas naturais dos alimentos por nitrogenio nåo protéico, com vistas a maior economicidade da ração.

Na avaliação correta de uma dieta afim de promover um aumento na produtividade animal, além dos estudos de qualidade da dieta e desempenho animal, torna-se desejável a mensuração dos parametros de fermentação ruminal como nitrogenio amoniacal, $p H$ ácidos graxos volateis.

Ao mesmo tempo, será necessario promover i mportantes alteraçäes na composiçăo dos rebanhos que formam a população de animais explorados economicamente pelo homem. Neste sentido, os bubalinos se enquadram perfeitamente por serem considerados como animais de grande futuro na produção de carne e leite e, de grande adaptabilidade aos mais variados sistemas produtivos.

- presente trabalho teve por objetivo avaliar 
os efeitos da substituiça parcial do farelo de algodao, ingrediente tradicionalmente empregado na alimentação dos ruminantes, pela uréia nos parametros fermentativos do 1 iquido ruminal de bubalinos em fase de crescimento. 


\section{REVISÃO DE LITERATURA}

2. 1. Utilização da ureia pelos microrganismos ruminais

A ureia alimentar ao chegar no rumem ó imediatamente hidrolisada pela urease bacteriana em amónia, gás carbônico e água, que será posteriormente incorporada à proteina microbiana, envolvendo reaçß̧es de desaminação transaminação, com produção de aminoácidos e cetoácidos no 1 iquido ruminal CVAN der HORST, $19,612$.

Segundo BURCHALL et ali $(1964)$, a presença de cofatores como NAD e NADP, associados a enzima desidrogenase Glutamica nos microrganismos ruminais, seria a base da fi xação da amônia.

Todaria, como a velocidade em que a uréia degradada à amónia no rúmen e quatro vezes maior do que a capacidade de incorporação da mesma por parte dos microrganismos (BLOOMFIELD, 1960), a eficiencia do processo 
fica sob a influencia de diversos fatores como a disponibilidade de carboidratos, proteinas, minerais e outros.

A qualidade e quantidade dos carboidratos, que compơem as raçธ̋es, são muito importantes na incorporação da amónia, pois os mesmos fornecem energia $e$ esqueleto carbonico aos microrganismos ruminais, determinando a velocidade de formação da proteina microbiana.

MCLAREN et alii clg65) observaram que 0 fornecimento de $100 \mathrm{kcal}$ de carboidratos facilmente fermenteciveis, corresponde a um incremento de $21 \%$ na retença de nitrogenio e, segundo os mesmos autores, seria necessario $1 \mathrm{~kg}$ de carboidratos fermenteciveis para o aproveitamento de $100 \mathrm{~g}$ de ureia fornecida. Entretanto, os carboidratos diferem amplamente nesta funça, sendo o amido - mais efetivo deles, enquanto que a celulose a menos eficiente de todos. O amido o mais eficiente por ser desdobrado no rúmen com a mesma velocidade em que a uréia hidrolisa-se en amonia, permitindo assim a maior incorporaçăo desta na proteina microbiana. Os açúcares e a celulose são inferiores ao amido como substrato, porque os primeiros desaparecem muito rapidamente, e a segunda transformada muito lentamente, não garantindo um suplemento adequado de energia para a realização da sintese da protel na mi crobiana.

MOTT et alii (1957), utilizando tres fontes de 
energia como suplementacăo da uréia: celulose (pasto), melaço $e$ milho, num periodo de 112 dias, constataram um ganho de peso de novilhas da ordem de $-7,5 ; 23$ e $27 \mathrm{~kg}$ respectivamente, demonstrando a maior eficiencia do amido como substrato para o aproveitamento da uréia.

VAN SOEST (1982) observou que a quantidade de amónia que pode ser incorporada na proteina microbiana, depende da quantidade de energia fermentecivel da raçă. Desta forma, PIDSEN (1971) sugeriu que $1 \%$ de nitrogenio na dieta era suficiente para utilização de forragens contendo menos de 50\% de energia digestivel (ED), mas que $1,5 \%$ eram necessários para forragem apresesentando maior concetração energetica e que, $2,0 \%$ deveriam estar presentes em dietas ricas em amido.

Estas afirmativas foram confirmadas por JORDAM \& SWANSSON (1979) que observaram maiores consumos, coeficientes de digestibilidade e produção leiteira, quando a ureia foi utilizada em dietas com silagem de milho, com o objetivo de elevar o teor de nitrogenio CND de 1,5 para 2, \%. Portanto, e segundo HUBER (1984), cada raçăo possui um teto de digestibilidade relacionado diretamente com a concentraçăo de energia digestivel acima do qual a ureia adicionada nå traz beneficios. Entretanto, fatores como: pH, nitrogenio disponivel, velocidade de passagem e outros parâmetros ruminais poderiam afetar este teto de digestibilidade. 
Assim como a digestibilidade dos carboidratos influi na sintese da proteina microbiana, SCOTT et ai $i$ i (1976) constararam que o nitrogenio da ureia deve representar uma alta porcentagem do nitrogenio total do alimento, para melhorar o seu aproveitamento pelos microrganismos. Estes pesquisadores observaram que quando uma raça se mostra com teores de proteina bruta (PB) acima de $18 \%$, os microrganimos dei xam de aproveitar o nitrogenio solúvel da uréia. Outros pesquisadores como SATIER \& SLYTER (1974) ROFLER \& SATTER (1975) chamam a atenç̃o para as 1 imitaçóes na utilização da uréia quando a porcentagem de proteina da ração excede a $13 \%$, uma vez que, provas "in vitro" evidenciam a incapacidade de bacterias em utilizarem amónia com eficiencia quando as concentraços excederam 5 a $8 \mathrm{mg} / 100 \mathrm{ml} e$, portanto, sua utilizaçăo mais recomendada como complementação aos alimentos de baixa qualidade.

Por outro lado, a presença de certa quantidade de proteina verdadeira, seja de origem animal ou vegetal, torna-se indispensável para a melhor utilização do nitrogenio não proteico (NNP). Isto porque BRYANT (1961) evidenciou que nem todas as bacterias ruminais podem se desenvolver somente às custas de amónia, necessitando para isto, de outras formas de nitrogenio, como peptideos ou aminoacidos, provenientes da proteina verdadeira. o mesmo autor, em estudo de bactérias ruminais, observou que das 44 bactérias isoladas, $80 \%$ poderiam crescer com amónia como 
fonte exclusiva de nitrogenio, 26\% não cresciam quando a amonia não estava presente e 55\% delas poderiam utilizar-se da amónia como do nitrogénio amínico.

Assim, ainda que se aceite que os microrganimos possam sintetizar aminoacidos a partir do NNP, MCLAREN et alii (1965) observaram uma retenção de $15 \%$ a mais de nitrogenio, em raçóes a base de uréia, quando se adicionam a mesma metionina, triptofano ou ambos. OLTJEN (1969) constatou que a substituiçăo completa da proteina por NNP, em dietas para ruminantes, pode reduzir ate $35 \% 0$ crescimento das bacterias e a retença de nitrogenio, em virtude da baixa sintese de aminoácidos essenciais.

Tambem deve-se acrescentar que a adição de certos aminoácidos atraves das proteinas pre-formadas, em complementação à uréia na dieta de ruminantes, além de suprir as necessidades em aminoacidos das proprias bacterias, os aminoácidos leucina, isoleucina e valina quando desaminados, serão fonte de energia através de seus isoácidos correspondentes, para que os microrganismos celuloliticos possam digerir mais eficientemente a celulose (HUNGATE, 1966 ).

$$
\text { Assim como os nutrientes discutidos }
$$
anteriormente, os minerais excercem marcada influencia na utilização do NNP pelos mierorganismos ruminais. Desta forma JONES et alii (1964) observaram que a atividade ureolitica positivamente influénciada pela presença dos minerais 
manganés, magnésio, cálcio, estróncio e bário e, negativamente, pelo sódio, potássio, cobalto, cobre, ferroe zinco. HUNGATE (1968) ressalta que dentre os elementos minerais, o fóforo, enxofre, magnesio e manganes são requeridos em maiores quantidades que os usuais para uma ótima utilização da uréia. Especificamente, o enxofre tem sua importância relacionada à formaçăo dos aminoacidos sulfurados (metionina e cistina) que sao limitantes na sintese de proteinas microbianas. Para tanto, recomenda-se uma relaçăo de nitrogenio:enxofre CN:S da ordem de 10 a 15:1, em dietas contendo nitrogenio não proteico.

2.2. Influencia da ureia en alguns parâmetros fermentativos do is çuido ruminal

As caracteristicas anatomicas do aparelho digestivo dos ruminantes, com seus compartimentos destinados ao armazenamento temporário dos alimentos, permite, graças aos mecanismos fisiologicos de manutençăo de temperatura, osmolaridade anaerobiose, a existencia de uma populaça microbiana que desenvolve intenso processo fermentativo, o qual se denomina fermentação prégástrica. Tal processo apresenta a caracteristica de continuidade, uma vez que ocorre a entrada constante de substrato com remoça dos produtos de fermentaçăo através de eructaça ou pela absorção na parede ruminal. Além disto, no processo de 
ruminaçăo, uma grande quantidade de saliva é adicionada com seus constituintes minerais, que conferem uma aça tamponante bastante eficaz, a qual confere estabilidade ao pH permitindo a sobrevivencia dos microrganismos.

Deste modo, os alimentos ingeridos se submetem a uma profunda transformaça no rumen, realizada pelos microrganismos que beneficiam o hospedeiro atraves de compostos de alta energia e proteinas de alto valor biologico, mesmo quando se utiliza como substrato alimentos grosseiros ricos em fibra e nitrogênio não proteico CMc NAUGHT et ali $i, 1954$.

Entretanto, esta condiçăo de equilibrio existente no rúmen extremamente influenciada pela dieta, que proporciona alteraç̧es notadamente nos parámetros pH, nitrogenio amoniacal acidos graxos volateis, como indicam os trabalhos de BALCH \& ROWLAND (1957); BATH \& ROOK (1963, 1965); ROFFER \& SATTER (1975) E LAVEZZO (1988).

E sobejamente conhecido que a raça ideal para a máxima utilização do nitrogenio deveria conter proteina de elevada digestibilidade e de baixa solubilidade no rúmen, uma vez que elevados teores de amónia são indicativos de baixa utilizaça de nitrogenio pelo ruminante. Assim, SATTER \& SLYTER (1974) determinaram com culturas microbianas "in vitro", que a síntese de protelna microbiana se estabiliza quando a concentraçăo de nitrogenio amoniacal ultrapassa a $5 \mathrm{mg} / 100 \mathrm{ml}$ de 11 quido 
ruminal. Posteriormente, ROFFLER \& SATTER (1975) efetuaram 35 ensaios experimentais com animais, utilizando sonda esofágica e, variando o nivel proteico com fontes exclusivas de proteinas naturais, também concluiram que o máximo crescimento microbiano ocorre quando a concentraçăo de nitrogenio amoniacal atinge $5 \mathrm{mg} / \mathrm{l} 00 \mathrm{ml}$ de 1 iquido ruminal, - que equivaleria a uma ração com $13 \%$ de proteina bruta. Baseados nestes experimentos, os autores concluiram que a prática de elevar o nivel proteico acima de 12 a $13 \%$ de proteína bruta com a adi̧ão de nitrogenio não protéico, além de não trazer beneficios ao crescimento bacteriano, não acarreta vantagens no binómio custo/benef 1 cio.

Entretanto, trabalhos de MEHZES et ai $i$ i (1977) - EDWARDS \& BARTLEY (1979) sugerem que sob certas condiços - nivel de $5 \mathrm{mg}$ de nitrogenio amoniacal para cada $100 \mathrm{ml}$ de 1 iquido ruminal pode ser muito baixo para o máximo crescimento microbiano.

Tal fato pode ser confirmado por KANG-MEZNARI CH \& BRODERICK (1980), que determinando o vol ume fisiologico do rumen, a velocidade de passagem 0 crescimento microbiano atraves dos marcadores ${ }^{35} s$ a acido diaminopimelico (DAP), observaram que o maximo crescimento microbiano ocorre quando a concentraça de nitrogenio amoniacal se encontra na faixa de 3,3 a $8,5 \mathrm{mg} / 100 \mathrm{ml}$ de 11 quido ruminal. Os mesmos autores concluiram tambem que, a eficiencia da produção da protelna microbiana diminue à 
medida que as taxas de nitrogenio amoniacal se tornaram execessi vamente altas.

$$
\text { Não obstante as consideraçôs supra }
$$

mencionadas, deve-se salientar que o aproveitamento do nitrogenio amonical está diretamente relacioando a disponibilidade de energia da dieta. Assim, segundo PIDGEN (1971), forragens com menos de 50\% de NDT tem poténcial energetico para aproveitamento de ate $1 \%$ do nitrogenio da dieta, enquanto que, aquelas com mais de $50 \%$ aproveitariam ate $1,5 \%$. E, somente dietas ricas em amido possibilitariam a utilização de niveis de $2 \%$ de nitrogenio.

os ácidos graxos volateis são a principal fonte de energia para os ruminantes, sendo produzidos no rúmem, a partir da fermentação dos carboidratos, em em especial da celulose, atraves de enzimas produzidas pelos microrganismos ruminais. Os carboidratos que se degradarem no rúmem irão produzir os ácidos graxos voláteis e gases. Os ácidos graxos voláteis, alem de fornecerem energia ao animal, tamberm estimulam o crescimento das papilas ruminais, sendo tambem, em parte, utilizados pelos proprios microrganismos para a sintese de seus polissacarideos celul ares (PONTES, 19813.

Tanto a concentraça dos acidos graxos volateis do rúmen, quanto a proporça entre os mesmos, estao sujeitos a inúmeras variaçôs.

Desta forma, a quantidade da dieta, o tamanho 
da particula o consumo alimentar são importantes fatores que afetam a fermentaç̃o no rúmen coRSKOV et alii, 1968 . Assim, MURDOCK \& HODEISON (1979) verificaram que a medida que diminuia o tamanho das particulas de feno ou se adicionava silagem de milho ao mesmo, ocorria uma diminuição na proporção entre os ácidos acético e propionico (Cz/Ca) da ordem de 3,83 para o feno em rama; 3,68 para o feno moído + $10 \%$ de silagem de milho e 2,83 para feno moldo + $20 \%$ de silagem de milho.

PONTES (1981) afirmou ser reconhecida a tendéncia de um aumento na concentração de acido acético e diminuição na concentração dos ácidos propiónico e butirico à medida que se aumentava o teor de fibra da raçăo. Para volumosos (forragens) a relaça acido acetico/propionico e normalmente maior que 3,0. MCDONALD et alii (1975) observaram que os concentrados modificam a fisiologia ruminal, em especial, quando presentes em alta quantidade $\theta$ com mudanças bruscas na dieta. Desta forma, aumentando-se os carboidratos soluveis da raçăo, as proporçôes dos ácidos graxos volateis são alteradas, aumentando o ácido propionico - diminuindo o acido acético, acarretando uma diminuiçáo do pH a valores abaixo de 6,0 , devido, em parte, a menor ensali vação proporcionada pelo menor tempo de ruminação. RUNSEY et alii (1970) comparando dietas de volumoso e concentrado, observaram que à medida que elevava-se o consumo de materia seca de 0,5 para $2,0 \%$ do 
peso vivo, correspondia a un aumento nos ácidos graxos volateis totais, diminuicăo da relaça acetico/propionico e do pH. Estes autores observaram nas dietas de volumoso e de concentrado, oscilaçסes do indice $\mathrm{pH}$ de 6,9 para 6,5 de 6.2 para 5,7, respectivamente; e um aumento de 115,9 a 183,6 mM/litro, para a concentraça de acidos graxos volateis, bem como uma reduçăo da relaçăo acético/propionicó de 5,1 a 4,4 e de 2,3 a 1,2 . Semelhante tendencia foi obtida por SINGH \& GUPTA (1986), trabalhando com diferentes niveis de nitrogenio protéco em dieta para bubalinos.

Com relação ao ácido acético, KOLB (1984) afirmou existir uma relação 1 inear entre a proporço molar deste ácido graxo volatil com o teor de fibra da raçăo. quando este valor fol superior a 15\%. MACHADO (1983) observou uma maior proporção molar de ácido acetico com raçăo contendo farelo de algodão em relação à dieta com levedura, em razão do maior teor de fibra da primeira.

Segundo PONTES $(1981)$, o pH normal no rúmen de 6,0 a 5,5 , mantendo-se estavel pela composição frequencia do alimento fornecido. $\bigcirc \mathrm{pH}$ otimo para digestão da celulose 60,5 , enquanto que, para a digestao du amido 6 abaixo de 6,0. ANNISAN, \& LEHIS (1966) relataram que com a diminuí̧ăo da taxa de fibra da raçăo, portanto, com o aumento dos carboidratos solúveis, altera-se a proporção dos ácidos graxos volateis. Ocorre diminuição na concentração do ácido acetico e aumento na concentraça do acido propionico 
e, modificaç⿰丿е irregulares na concentração do acido butirico. A isto, acompanha-se uma diminuição na ensali vação, consequientemente na atividade tamponante $\theta$, como resultado desta cadeia de fatores, o pH cai a níveis proximos de 5,0. Nestas condicores, o pH torna-se muito instavel provocando a morte das colonias de microrganismos, sobretudo de protozoarios ciliados.

A influencia do $\mathrm{pH}$ nos parámetros ruminais foi determinada por ERFLE et ali $i$ (1982), trabalhando com rúmen artificial. Estes autores observaram que uma diminuiça do pH de 7,0 para 5,0, acarretou um decréscimo na concentraçăo de acidos graxos volateis de 80 para $50 \mathrm{mM} / \mathrm{dia}$, com diminuição na taxa de produçå de ácido propiónico e diminuigă de acido butirico. A relaça acético/propiónico de 4,3 em $\mathrm{pH} 7,0$, passou para 0,9 em $\mathrm{pH} 5,0$. Finalmente, 0 N-NHa variou de 4 a $6 \mathrm{mM}$ em $\mathrm{pH} 6,0$ e 7,0 - $0,2 \mathrm{mM}$ em $\mathrm{pH} 5,0$ e 5,5.

As principais bactérias produtoras de ácido propionico fazem sua sintese atraves do lactato e requerem um pH otimo de 6,o segundo ANNISON \& LEHIS (1966) BALCH \& ROWLAN (1987). Entretanto, SATTER et ali $(1974)$, estudando "in vitro" a degradaçăo da celulose e hemicelulose. observaram que houve produçăo de acido propiónico pela via do succinato.

BATH \& ROOK (1963) observaram, por outro lado. que - tipo $e$ a quantidade da proteina podem afetar a 
concentraça dos ácidos graxos volateis, aumentando a proporça de ácido butírico. Alem disso, segundo os mesmos autores, a utilizaça de sacarose como fonte de carboidrato prontamente disponivel produz aumentos similares nos acidos propisnico e butirico.

o aumento de ácido butirico no 11 quido ruminal pode ser atribuido a uma maior proporgão do ácido acético, pois, trabalhos experimentais mostram que 40 a $80 \%$ do ácido butirico formado no rúmen consequéncia da atuaçăo de microrganismos que transformam dois moles de acido acético em um mol de ácido butírico CCHURCH, 1979 .

GRIFFITHS \& BATH (1973) relataram que em dietas com predominância de vol umosos, mesmo que se adicione suplementos proteicos de origem vegetal ou sob a forma de NNP, não acarretam abaixamento do pH para valores menores do que 6,0 , concluindo que as dietas com predominancia de forragens devem apresentar pH proximo da neutralidade.

A frequiencia alimentar também exerce pequena influéncia no pH. BATH \& ROOK (1963) observaram que aumentando-se o número de refeiçós de uma para quatro vezes ao dia, a variação no $\mathrm{pH}$ foi de 6,52 a 6,33. Da mesma forma, PUTNAN et alii (1966) observaram pequenas alteraçäes no Indice pH à medida que se elevava o consumo alimentar de 0,8 a 1,4\% para 2,0 e,6\% do peso vivo.

\section{SATTER \& BAUNGARDT (1962) verificaram uma} maior flutuaça nas taxas de acidos graxos volateis totais, 
N-NHa e $\mathrm{pH}$, quando aumentaram a frequiencia de alimentaça de duas para oito vezes ao dia.

Alem dos carboidratos, as proteinas e aminoácidos também se constituem em fontes de acidos graxos volateis, notadamente os de cadeia ramificada, como o sao o isobutirico, e-metil-butirico, isovalerico isocaproico; os quais tem seus niveis aumentados a partir do ataque microbiano de proteinas no rúmen CEL SHAZLY, 19523.

HUNGATE (1966) observou que o aminoacido prolina pode ser reduzido a ácido n-valerico, considerado um dos fatores de crescimento para algumas colonias de bacterias celuloliticas, importante fator para animais al imentados com dietas a base de volumosos.

A digestibilidade da proteina no 1 lquido ruminal diretamente proporcional a sua solubilidade. Assim sendo, as proteinas de origem vegetal, por liberarem a amónia mais lentamente, alem de produzirem os isoácidos que são utilizados como fonte de energia para os microrganismos, parecem ser mais eficientemente utilizadas para a sintese de proteina microbiana do que as fontes de nitrogenio não protéco de rápida degradabilidade.

Isto pode ser comprovado pelos trabalhos de AHRAR \& SCHINGOETHE (1979), que observaram baixas taxas de ureia no plasma de ruminantes alimentados com proteinas de baixa solubilidade, concluindo que a amônia liberada no rúmen foi utilizada mais eficientemente. 
Por outro lado, a degradaça da uréla no rúmen, por ser muito intensa, favorece uma elevaça do pH pela liberação da amónia. AZIZ \& MIR (1986), trabalhando com bubalinos, determinaram elevaçbes nas taxas de $N-N H 3$ C 19,8 para $24,12 \mathrm{mM} / 1)$ no indice $\mathrm{pH}$ (6,9 para 7,05 quando a fonte proteica era a ureia. Este fato aumenta a permeabilidade do epitelio ruminal e, consequientemente a passagem da amónia para a corrente circulatória, principalmente quando o $\mathrm{pH}$ ruminal estiver acima de 7,5 (BLOOMFIELD, 1963). Todavia esta absorçăo é muito lenta quando o pH estiver abaixo de 6.7 CSMITH, 1975). 0 desaparecimento da amónia em $\mathrm{pH}$ inferior a 7,0 deve ser considerado como reflexo de sua utilização pelos microrganismos ruminais (NOLAN et ali $i, 1973$ ).

KAPOOR et ali $(1987)$, comparando a produça de acidos graxos volateis no rumen de bubalinos alimentados com uma dieta basal o suplementadas com melaço-ureia, observaram nesta última uma redução significativa na produçăo de acidos graxos volateis totais, que foi atribuida a qualidade da proteina; bem como um aumento significativo na produção de ácido propionicc e redução na produçãodo ácido acético, em virtude da maior disponibilidade da açucares fermenteci veis pela adição do melaço.

MAHADEVAN et ali $i$ (1982), comparando uma dieta padrão concentrado + feno de alfafas com outra a base de silagem de milho com ureia, ambas com aproximadamente $16 \%$ de 
PB, observaram que na dieta contendo uría ocorreram as maiores taxas de produça e utilizaça do $\mathrm{N}-\mathrm{NHa}$, evidenciadas pela maior taxa de desaparecimento de amónia, a qual foi coincidente com os periodos de maior produça de acidos graxos volateis, indicando uma maior utilizaçăo de amonia pelas bacterias. Os mesmos autores observaram uma alta correl ação negativa entre concentração de ácidos graxos volateis e $\mathrm{pH}$, da ordem de $r=-0,86$ a $-0,94$.

PANT \& ROY (1970) comparando alguns parâmetros do liquido ruminal de bubalinos e zebuinos, coletados mediante sonda esofagiana em diferentes horários apos a alimentação, observaram um decréscimo do nitrogennio solúvel e N-NHэ, após duas horas, em ambas as especies, embora estes valores tenham sido superiores nos bubalinos. STEWART et alii (1958) estudando dietas de feno de alfafa com ou sem suplementação de uréia concluiram que as taxas de produçăo de ácidos graxos volateis eram maximas dentro das duas primeiras horas apos a alimentacão e que após cada alimentaça ocorreram quedas no $\mathrm{pH} e$, a ur bia nao estimulou marcadamente a produçăo de ácidos graxos volateis.

FREITAG et ali (1968), estudando dietas com alto e baixo niveis de proteina $(11$ e $7 \%$ e utilizando como fonte proteica farelo de soja ou ureia observaram, atraves da coleta do 1 iquido ruminal com sonda esofágica, a inexistencia de diferenças significativas para os parametros ácidos graxos volateis totais, ácido propionico, acido 
acético e butifico, entre niveis proteicos e fontes de proteínas.

PANDE \& SHUKLA (1981), trabalhando com tres dietas e dois niveis de proteina sendo uma delas com $20 \%$ de substituiça da protelna por ureia, observaram em amostras do liquido ruminal de búalos colhidas atraves de sonda esofagica, que o indice $\mathrm{pH}$ - $0 \mathrm{~N}-\mathrm{NH} 3$ foram estatisticamente superiores para o tratamento contendo uréia, enquanto que, os acidos graxos totais apresentaram um comportamento inverso.

2.3. Tempos de amostragem

Em recente revisão sobre as curvas de AGV, N-NH3 e Indice $\mathrm{pH}$, LAVEZZO (1986) relatou oscilaçes ciclicas nestes parametros, com a ocorrencia de picos ate 8 horas apos a ingestão de alimentos, confirmando assim as observaçaes de MCDONALD (1952); SCHAADT \& JOHNSON (1969); MAHADEVAN et ali $(1982)$ e LANGAR et ali $(1984)$.

Assim, com relação aos ácidos graxos voláteis, LAVEZZO (1986) observou que 1 a 2 horas apos a ingestao do al imento ocorria o pico máximo de produção dos mesmos. Por outro lado, dietas ricas em volumosos, em virtude de uma degradação mais lenta, podem apresentar um pico de produçăo dos AGVs mais tardiamente (HUNGATE, 1966). Em dietas suplementadas com ureia, PANDE \& SHUKLA (1981) relataram um 
pico de produção dos AGVs 3 horas apos a alimentaçăo.

A elevação da concentraçăo de amonia também ocorre logo após a ingestão dos alimentos, alcançando um máximo de 2 a 4 horas (LAVEZZO, 1986). Estes resultados estão um pouco acima dos observados por PANDE \& SHUKLA (1981) $e$ KOLB (1984), que constataram a máxima produção 1 a e horas após a alimentação. Deve-se ressaltar entretanto, que os picos de maxima produçăo de $N$-NHa estão relacionados com a solubilidade da fonte nitrogenada, sendo mais rápida para as fontes de nitrogenio não proteico e mais lentas para as fontes de proteinas verdadeiras CBUCHANAM-SMITH \& YAO, 1978 P PANDE \& SHUKLA, 19812.

Em relação ao indice $\mathrm{pH}$, ocorrem valores mais baixos usualmente 1 a 2 horas apos a ingestão do alimento (LAVEZZO, 1986$)$ OU 2 a 4 horas segundo BALGH \& ROWLAND (1957) PANDE \& SHUKLA (1981), conforme a qualidade e quantidade da raça.

A variação no indice pH está relacionada ás mudanças nas concentraç̧es de AGVS, bem como pela quantidade de saliva produzida, ou seja, pela taxa de diluiça ruminal CSINGH \& SUD, 19812.

2.4. Metodos de coleta e animais utilizados

Na obtenção de amostras do 11 quido ruminal visando o estudo dos parametros ruminais, dois métodos tém 
sido preconizados, ou seja, via fistula ruminal ou via sonda. esofágica. Ambos os metodos de coleta apresentam vantagens e desvantagens. Assim sendo, o método de coleta por sonda esofágica tende a ser um tanto insatisfatorio para determinar a magnitude dos parametros de fermentaçăo mensurados, conforme demonstrou LAVEZZO (1986), que observou valores maiores no $\mathrm{pH}$, e menores para $\mathrm{N}-\mathrm{NH}$ e AGV totais, quando da coleta de amostras por este método.

Entretanto, a sonda esofágica tem sido 1 argamente utilizada para a retirada do 1 iquido ruminal em animais intactos, com resultados satisfatorios como concluiu RHODES (1961), que detectou maior sensibilidade na coleta via sonda, quando mensurou a relação ácido acetico/propionico em animais submetidos a diferentes dietas. Analisando o mesmo parametro, RAUN \& BURROUSHS (1962) observaram bastante sensibilidade neste método $\theta$ concluiram que os valores do $\mathrm{pH}$ AGVs obtidos eram muito semelhantes, nå, induzindo a erros nas mensuraçoes quando compararam os dois metodos de coleta.

Além disto, o metodo de coleta via sonda tem sido bastante racomendado para se ter uma indicacão de como se comportam as dietas com respeito ao padrão de fermentaça ruminal, como demonstraram os trabalhos de RAUN et alii (1962); FREITAG et alii (1968); RUNSEY et alii (1970) PANDE \& SHUKLA (1981).

Existem na literatura variaçßes no tocante aos 
dados referentes aos parâmetros de fermentação ruminal entre animais, devido às diferenças anatomo-fisologicas, mesmo fornecendo-se uma mesma dieta CGRIFFITHS \& BATH, 1973 . Neste sentido, PATHAK et alii (1973), comparando alguns parametros ruminais como pH, AGVs totais, acido acetico, ácido proplónico, ácido butírico e $\mathrm{N}-\mathrm{NH} 3$ para dietas contendo melaço-ureia, năo observaram diferenças estatisticamente significativas entre bubalinos e zebuinos. Por outro 1ado, LANGAR et ali $i$ (1984) observaram diferenças significativas entre bubalinos e zebuinos para parametros fermentativos como AGV totais e $\mathrm{N}-\mathrm{NH3}$, concluindo que os búfalos são mais eficientes na utilizaçăo da uréia.

ICHHPONANI \& SIDHU (1965) mostraram que as concentraç̋es de AGVs no rumen de bufalos eram significativamente maiores do que de zebuinos, quando submetidos à mesma dieta. Aos mesmos resultados chegaram ICHHPONANI et alii (1968). PANT \& ROY (1989), investigando a flora e fauna ruminal de bubalinos e zebuinos, observaram marcadas diferenças quanto à concentração de bactérias, mas não quanto a de protozoários ciliados.

COCKRILL (1974) afirmou que existem variaç̧es anatomicas, fisiologicas e histologicas, bem como na popul aça microbiana do rumen entre bubalinos e bovinos, as quais seriam responsaveis pela maior eficiência no aproveitamento das fraçes fibrosas das dietas pelos búfalos. 


\section{MATERIAL E METODOS}

O trabalho experimental foi conduzido junto ao Núcleo de Bubalinos mantido pelo Convenio FINEP-UNESP-FMVZ da Fazenda de Ensino, Pesquisa e Produção, Estação Experimental Lageado, da Faculdade de Medicina Veterinária $\theta$ Zootecnia, UNESP, Campus de Botucatu.

Foram utilizados 20 búfalos machos em fase de crescimento, com idade media de 12 meses e peso vivo medio de $218 \pm 18 \mathrm{~kg}$. Os animais foram divididos em dois lotes de 10 animais cada, de maneira a torna-los o mais uniforme possivel quanto ao peso medio e ao aspecto geral dos mesmos, em relação à altura, comprimento e cobertura muscular. Ambos os lotes foram submetidos a um perfodo preliminar de 28 dias de arraçoamento para a adaptaça às respectivas dietas.

As dietas experimentais foram fornecidas uma yez por dia, pela manhã, com sua composiçăo constituida em volumoso a base de cana-de-açúcar cSaccharum of ficinarum L., 
2-13-248) colhida e picada diariamente e um concentrado a base de rolão de milho (zea mays, L., 1-28-e33) ao qual era adicionado farelo de algodão (5-01-625) e ureila (5-05-070), com a substituiça de $15 \%$ da proteina da dieta por uréia, conforme a Tabela 1 .

Tabela 1. Composiça centesimal das dietas experimentais fornecidas a cada lote.

\begin{tabular}{|c|c|c|c|c|}
\hline \multirow{2}{*}{ Ali mentos } & \multicolumn{4}{|c|}{ Dietas $6 \%$} \\
\hline & & A & & B \\
\hline Ralão de Milho & & 80 & & 70 \\
\hline Farelo de Algodão & & 40 & & 29 \\
\hline Ureia & & - & & 1 \\
\hline Cana de açúcar & ad & libitum & ad & libitum \\
\hline
\end{tabular}
$A=$ raça em que a principal fonte proteica era o farelo de algodå
$B=$ raçăo em que a fonte proteica foi parcialmente subs- tituida por ureia.

Atraves da análise bromatológica das raçes,

realizada no Laboratorio de Bromatologia da Faculdade de Medicina Veterinária e Zootecnia, UNESP, Campus de Botucatu, revelou-se teores de 16,4 e $16,7 \%$ de proteina bruta para as raçóes $A$ e $B$, respectivamente. Os nutrientes digest 1 veis totais (NDT calculados de acordo com as tabelas de composição do NRC (1984) indicou valores de 68 e $67 \%$ para as mesmas.

Todos os animais tinham acesso a agua e sal mineralizado "ad libitum". 
Nos periodos de coleta, na quantidade de uma coleta/animal/dia em cada tempo de amostragem, as raçбes eram fornecidas na quantidade de $3 \mathrm{~kg} / c a b e c a / d i a, ~ m i s t u r a d a s$ à cana-de-açúcar numa quantidade tal que os animais a ingerissem em um tempo médio de 30 minutos.

As coletas de 11 quido ruminal foram feitas em cada animal individualmente, atraves de sonda esofagiana, nos tempos $0,1,3$ e horas após a alimentacão.

A amostragem do liquido ruminal via sonda esofagiana seguiu a tecnica descrita por HOFIREK (1970), que constava de um tubo de borracha flexivel de $0,8 \mathrm{~cm}$ de diametro interno, o qual era introduzido no rúmen através do esofago, tendo como guia um tubo flexivel formado por espirais de aço inoxidavel de aproximadamente $1,70 \mathrm{~m}$ de comprimento. No momento da extraça do 1 íquido ruminal, utilizoüse um vácuo de aproximadamente $1,05 \mathrm{kgf} / \mathrm{cm}^{2}$. 0 Iiquido tinha a sua primeira porcăo descartada, sendo o restante colocado em recepiente de plástico encaminhado para as determinaçßes de nitrogenio amoniacal (N-NHa), pH e ácidos graxos volateis CAGV.

As mensuraçzes de $\mathrm{pH}$ foram feltas Imediatamente apos a coleta das amostras de 1 iquido ruminal, em becker de vidro, atraves de um potenciometro marca Micronal B-2el, devidamente calibrado.

Para a mensuração das concentraçð̋s de $\mathrm{N}-\mathrm{NH3}$ no 11 quido ruminal, as amostras eram filtradas atraves de 
pano de queijo. Do filtrado, tomava-se uma al iquota de $6 \mathrm{ml}$ a qual era transferida para outro frasco contendo $3 \mathrm{ml}$ de $\mathrm{H}_{25} \mathrm{SO}_{4} \mathrm{~N}$, fechado, e mantido sob congelamento a $-15^{\circ} \mathrm{C}$. Para a determinação analitica a amostra era descongelada e após agitaçăo, retirava-se $3 \mathrm{ml}$ da mistura 1 iquido ruminal + $\mathrm{HzSO}_{4} 1 \mathrm{~N}$, que era transferida para um tubo de ensaio ao qual era adicionado $1 \mathrm{ml}$ de tungstato de sodio $10 \%$, seguindo-se entå a marcha analitica indicada por KULASEK (1972) e adaptada por FOLDAGER (19772. As determinaços foram feitas em triplicata, utilizando-se de brancos e comparadas com a curva padrăo, obtida atraves do uso de uma solução de sulfato de amónia, na diluiçăo de $1 \mathrm{mg} / \mathrm{ml}$. As leituras de absorbancia foram feitas a $640 \mathrm{~nm}$, em espectrofotometro marca Spectronic 20.

Para as mensuraçóes de ácidos graxos volateis CAGV no liquido ruminal, após as amostras coletadas serem filtradas, eram retirados do filtrado $3 \mathrm{ml}$ os quais eram transferidos para frascos com tampa, contendo $3 \mathrm{ml}$ de acido metafosfórico $6 \%$. Estes recepientes eram então mantidos sob refrigeração em $4{ }^{\circ} \mathrm{C}$ ate a centrifugaçåo a 3000 rpm por 15 minutos. Ds AGV forar determinados segundo a tecnica descrita por ERHIN et alii (1961), através de aparelho de cromatografia gasosa de Marca CG, modelo 370, equipado com coluna Chromosorb 101 , pela comparaçăo dos gráficos obtidos para as amostras com os obtidos para uma solução padrăo, descrita pelo método acima citado. 
Para a analise estatistica dos dois tratamentos compreendidos por um conjunto de 10 animais cada e avaliados em quatro tempos $c_{1}=0, t_{2}=1, t_{3}=3 \mathrm{e}_{4}=$ o horas) após a ingestão, utilizou-se a Análise de Perfil CMORRISON, 1967). Este metodo estatistico leva em consideração a estrutura de dependencia das medidas efetuadas ao longo do tempo, no mesmo conjunto de animais. Em todas as hipóteses testadas, as estatisticas calculadas $C F$ ou $t)$ foram ditas significativas quanto $P<0,05$, onde $P$ \& - nivel de significancia associado a estatistica calculada. 


\section{RESULTADOS E DISCUSSAO}

Nas tabelas apresentadas neste capitulo, os dados se referem aos valores medios dos resultados obtidos para as diferentes variáveis estudadas. Sao apresentadas também informaçoses relativas a análise estatistica, caracterizando os efeitos significativos CP<0,055 obtidos através da análise de variancia e dos testes de comparação de medias (Teste "t") entre os grupos independentes.

Na Tabela 2 são apresentados os valores médios da concentração de $N-N H 3$ (mg/dl) no 1 iquido ruminal de bubalinos, arraçoados com duas dietas experimentais a com amostragens realizadas às $0,1,3 \notin 6$ horas após a alimentaçă, cujos valores eståo ilustrados nas figuras 1 e 2. Na Tabela 3 encontra-se a analise de variancia referente a Tabela 2 .

Os dados médios de concentração de N-NH3 observados na Tabela 2 , mostram que existiu uma interaça 
significativa $C P<0,01\rangle$ entre os tratamentos $e$ os tempos experimentais, indicando que os perfis dos dois grupos de animais não são similares, demonstrando a ocorrencia de diferentes taxas de produção elou absorçăo de $\mathrm{N}-\mathrm{NH}$ a no rúmen entre as duas dietas utilizadas. Assim, as concentraç̧es de amônia são bastante variáveis em ambas as dietas e nos diferentes tempos de coleta, sendo que estes fatores refletem as diferenças existentes entre as dietas no tocante a solubilidade, taxa de hidrólise, bem como a presença de carboidratos fermenteciveis e outras.

A Tabela 2 indica ainda que houve uma semelhança entre as raç̃es com relação a produça média de $\mathrm{N}-\mathrm{NH} 3$, com os valores de $17,03 \mathrm{mg} / \mathrm{dl}$ para a dieta com farelo de algodåo $16,25 \mathrm{mg} / \mathrm{dl}$ para a dieta com ureia. Estes resultados indicam que ambas as dietas experimentais forneceram igualmente $\mathrm{N}-\mathrm{NH}$ ( para 0 desenvolvimento bacteriano CANNISON \& LEWIS, 1960), no periodo estudado.

Desta forma, pode-se observar que, independentemente das fontes proteicas utilizadas, as concentraçós médias de $\mathrm{N}-\mathrm{NHa}$ no 11 quido ruminal tendem a ser semelnantes quando se utilizam dietas isoproteicas, como observaram PANDE \& SHUKLA (1981) trabalhando com protelna verdadeira e ureia, obtendo valores de 25,04 e 27.71 mg\%, respectivamente e por LAVEZZO (1986) que observou valores de 10,25 e $10,28 \mathrm{mg} / \mathrm{dl}$, respectivamente para as dietas com levedura alcoolica farelo de algodão. 


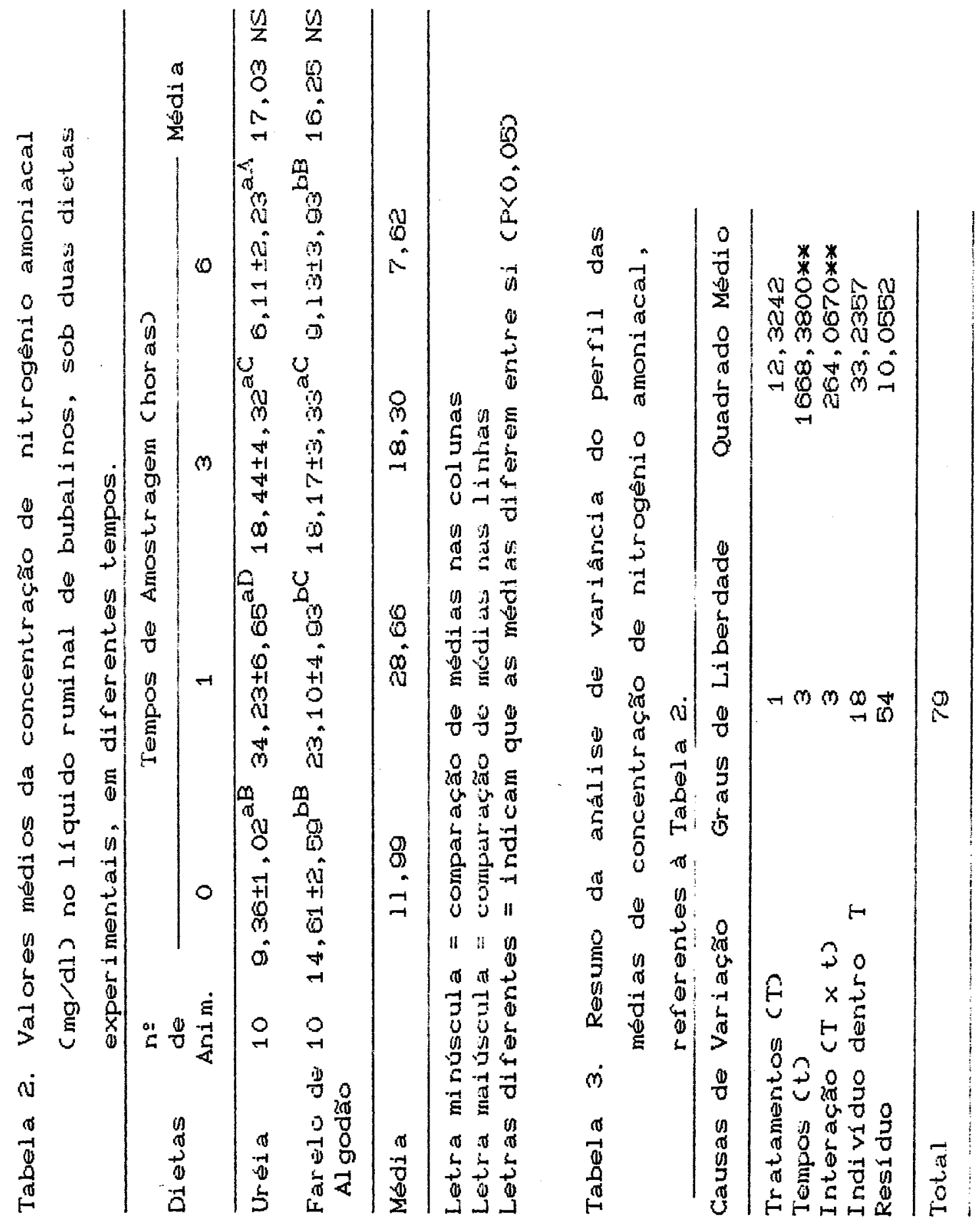


No presente trabalho, as concentraç̋̈es médias de $17,03 \oplus 16,25 \mathrm{mg} / \mathrm{dl}$ obtidas com dietas contendo em média 16,5 de $P B$ e 68\% NDT, estão bastante proximas às apresentadas por SATTER \& ROFFLER (1976), que estimaram a concentraçăo média de amónia a partir dos niveis de proteina e energia da raçăo.

Os valores medios da concentraça de $\mathrm{N}-\mathrm{NHa}$ no presente trabalho foram de 11,$99 ; 28,66 ; 18,30$ e 7,62 $(\mathrm{mg} / \mathrm{dl})$ respectivamente, para os tempos $0,1,3$ e horas apos a alimentaça, independente da fonte de nitrogenio, observando-se que as maiores medias de produça de $\mathrm{N}-\mathrm{NH}$ ocorreram 1 hora após a ingestão do alimento.

No tocante a dieta contendo uréia, que apresentou os valores de 9,$36 ; 34,23 ; 18,44 \ominus 6,11 \mathrm{mg} / \mathrm{dl}$ nos tempos $0,1,3$ e 6 respectivamente, detectou-se diferenças estatisticamente significativas entre estes valores $(P<O, O 5)$, com maior produça de $\mathrm{N}-\mathrm{NH3} 1$ hora apos a alimentaçăo. $\mathrm{Da}$ mesma forma, os valores de $\mathrm{N}-\mathrm{NH}$ a para a dieta contendo farelo de algodão foram de 14,61; 23,10 ; 18,17 e $9,13 \mathrm{mg} / \mathrm{dl}$ respectivamente para os tempos $0,1,3$ e o horas, cuja arálise de variancia detectou diferenças estatisticamente significativas $C P<0,05)$ entre os mesmos, com excecão entre os valores referentes aos tempos 1 e 3 horas apos a alimentaça, onde ocorreram os valores mais elevados de produçăo.

Estes comportamentas encontram suporte na 
literatura, uma vez que PANDE \& SHUKLA (1981), amostrando via sonda esofágica o liquido ruminal de bubalinos arraçoados com dietas com ou sem ureia, obtiveram picos de concentraçăo de $\mathrm{N}-\mathrm{NH3}$ em 1 a 2 horas após o fornecimento das dietas, respectivamente. Estes dados tambem estão sustentados na afirmaçăo de BUCHANAM-SMITH \& YAO (1978), os quais relacionaram a concentraçăo de $\mathrm{N}-\mathrm{NH}$ a a solubilidade da fonte de nitrogenio, afirmando serem as proternas verdadeiras de mais lenta degradaço e as fontes de NNP de mais rápida.

No tempo $t=0$ hora, observou-se as medias de 9,36 e 14,61 mg/dl para as dietas com uréia e farelo de algodão, respectivamente. Esta diferença estatisticamente significativa $C P<0,05$ deve-se a baixa degradabilidade de proteina verdadeira no rumen, fornecendo substrato nitrogenado residual aos microrganismos ruminais, antes mesmo do período de alimentação.

No presente trabalho, a não existencia de diferenças estatisticas $C P<0,05$ entre os tempos 1 e 3 horas de amostragem, para a dieta formulada com farelo de algodão, indica que o pico de concentração de N-NH3 ocorreu entre 1 e 3 horas, como ficou consubstanciado por LAVEZZO (1986), que tambem trabalhando com farelo de algodå, encontrou o pico de produçăo de $\mathrm{N}-\mathrm{NHz}$ de 2 a 4 horas após a ingestão.

As Figuras 1 e mostram o comportamento das 
concentraçbes de $\mathrm{N}-\mathrm{NH3}$ nos diferentes tempos, onde os valores mais elevados foram registrados entre 1 e horas. Mostra ainda que as concentraç̧es de $\mathrm{N}-\mathrm{NH} 3$ em ambas as dietas apresentaram valores altos, acima do nível de 5 mg/dl, defendido por SATTER \& SLYTER (1974) e ROFFLER \& SATTER (1975), como sendo o ideal para o máximo crescimento bacteriano. Isto indica que os microrganismos ruminais foram supridos com quantidades de $\mathrm{N}-\mathrm{NH3}$ acima da necessaria, no periodo estudado. Entretanto, se considerarmos o nivel de $8,5 \mathrm{mg} / \mathrm{dl}$, preconizado como ótimo por KANG-MEZNARICH \& BRODERICK (1981), poderiamos observar que no presente trabalho, 6 horas após a alimentacăo, a dieta suplementada com ureia estaria com uma concentraçăo de $\mathrm{N}-\mathrm{NH3}$ inferior, ao passo que a dieta com farelo de algodå ainda estaria ligeiramente superior. E ainda, relativamente inferior aos dados obtidos por MEHREZ et alii (1977), que indicam 23,5 mg/dl de 1 iquido ruminal como sendo a concentração minima de N-NHz, para a máxima taxa de fermentaça. 


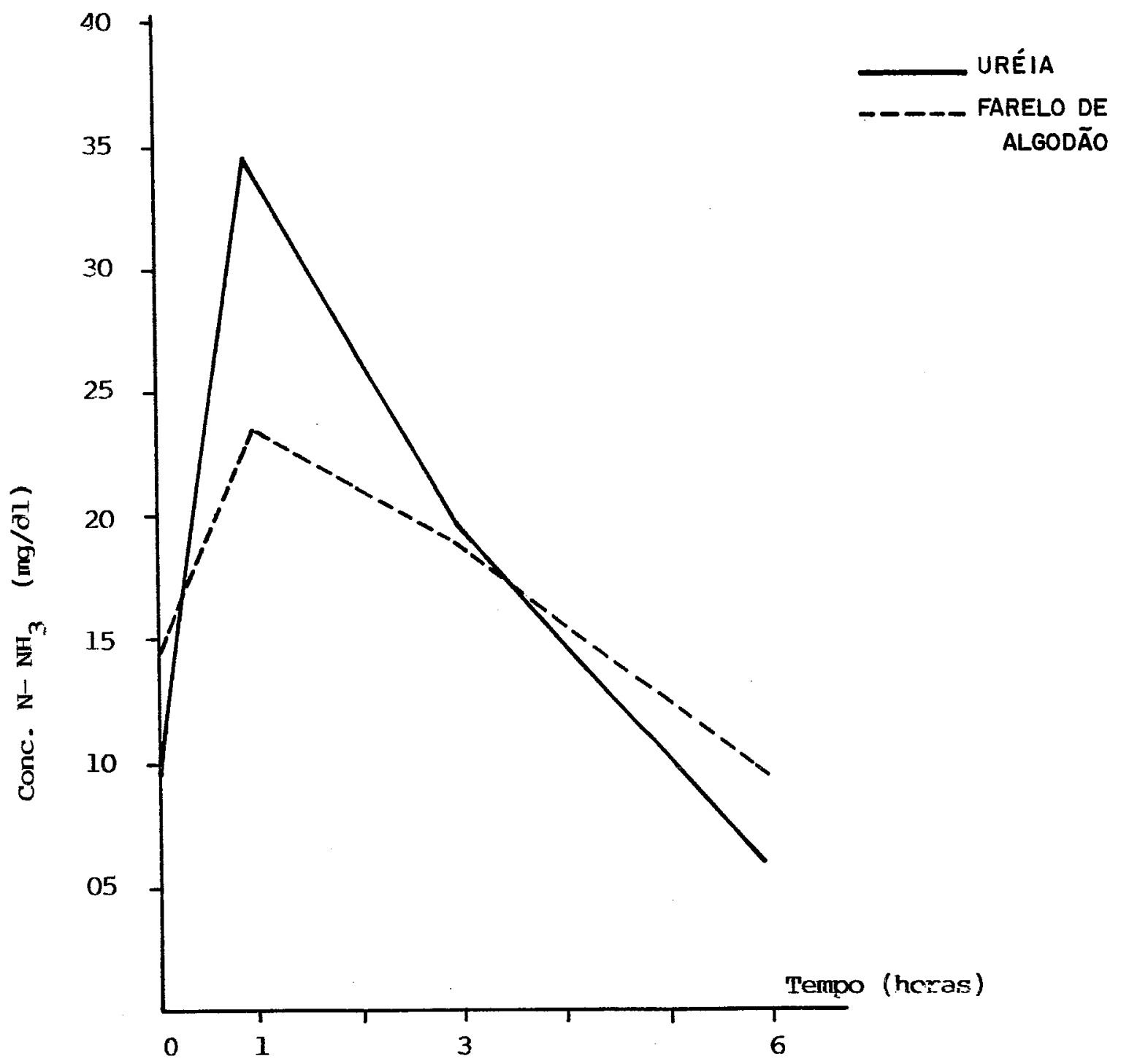

Figura 1. Niveis médios de nitrogenio amoniacal em 11 quido ruminal de bubalinos, sob duas dietas e em quatro tempos experimentais 


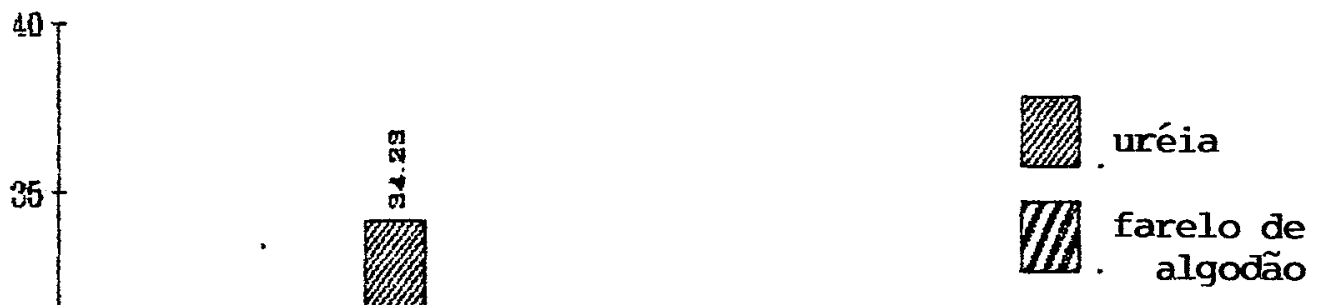

Figura 2. Niveis médios de nitrogenio amoniacal em liquido ruminal de bubalinos, sob duas dietas e em quatro tempos experimentais 


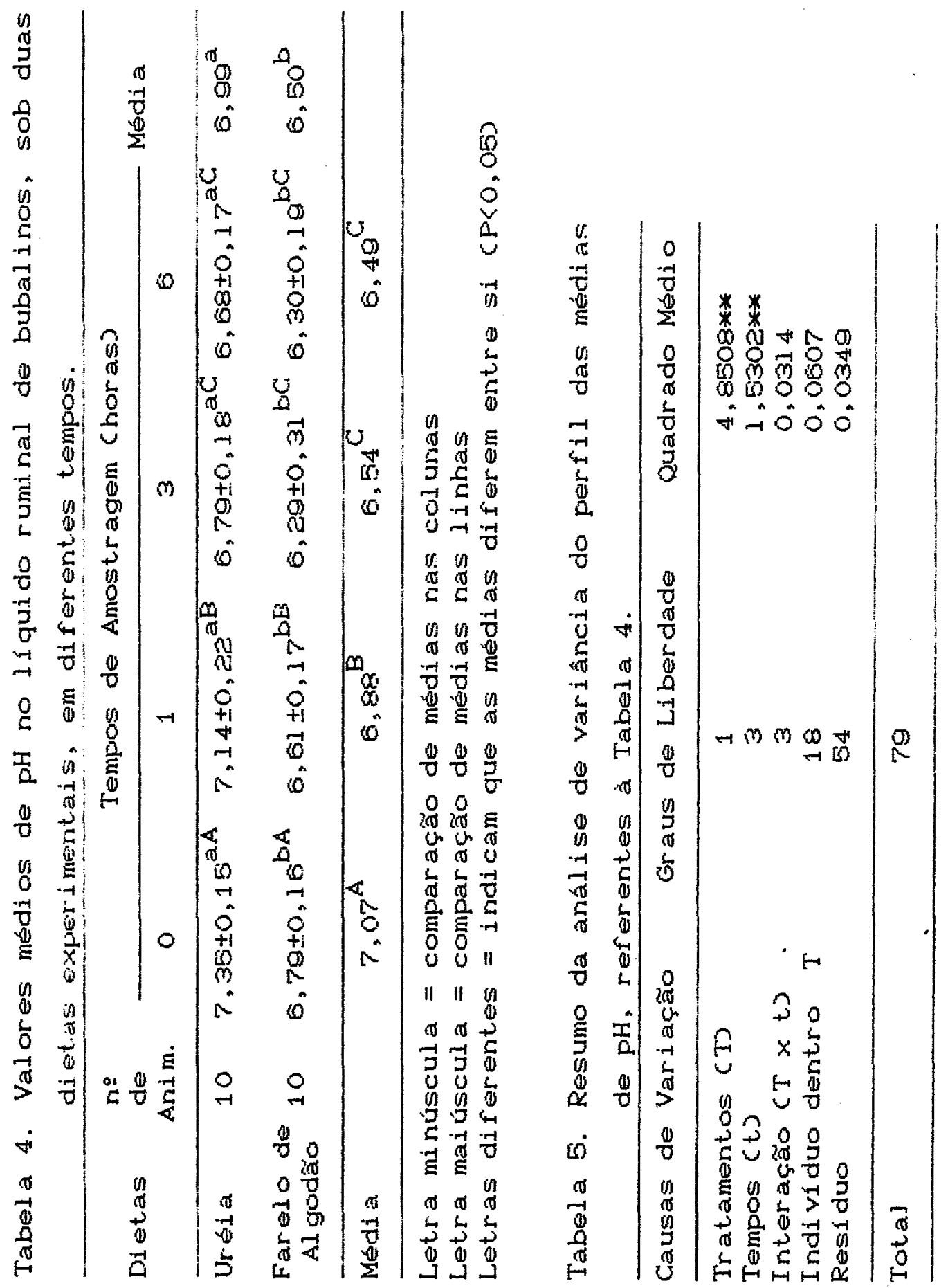


Este excesso de $\mathrm{N}-\mathrm{NHa}$ no 1 iquido ruminal deve-se em parte ao alto teor de proteina das dietas experimentais, bal anceadas para $18,5 \%$ de $P B$ e, também aos baixos valores médios do $\mathrm{pH}$ obtidos, de 6,99 6,50 , respectivamente, para as dietas com ureia e farelo de algodão, pois a absorção de amónia para a corrente circulatória rápida somente quando o $\mathrm{pH}$ for superior a 7,5 (BLOOMFIELD, 1963), e muito lenta quanto este indice estiver abaixo de 6,7 (SMITH, 1975$)$.

As altas concentraçß̋es de $\mathrm{N}-\mathrm{NH} 3$ registradas nesta pesquisa, indicam que o nivel de $16,5 \%$ de $P B$ das dietas experimentais esteve acima das necessidades dos microrganismos do rúmen de bubalinos em fase de crescimento. Na Tabela 4 são apresentados os valores médios do $\mathrm{pH}$ no líquido ruminal de bubalinos arraçoados com duas dietas experimentais e com amostragens realizadas $0,1,3$ e 6 horas após a alimentação, cujos valores estão ilustrados nas Figuras 3 e 4 . Na Tabela 5 encontra-se a analise de variancia referente a Tabela 4.

A análise estatistica dos resultados não revelou haver interação entre as duas dietas (P>0,10) indicando que os perfis são similares, ou seja, para ambas as dietas, os valores de $\mathrm{pH}$ se comportaram de maneira semel hante ao longo do tempo.

os valores médios de pH registrados na Tabela 4, mostram haver diferenças estatisticamente significativas 
$C P<0,05\rangle$ entre as dietas com ureia e farelo de algodão, cujos valores foram de 6,99 e 6,50 respectivamente, independente do tempo da amostragem e, analisando as diferenças entre os tratamentos, observa-se que em todos os tempos experimentais houve uma superioridade significativa $C P<0,01)$ para a dieta contendo ureia, o que pode ser atribuido às baixas concentraçóes de ácido orgânico devido à rápida degradabilidade da ureia no rúmen, com menor disponibilidade de substrato nitrogenado residual, mesmo considerando-se $t=0$.

Os valores medios do indice $\mathrm{pH}$ obtido nesta pesquisa $(6,99 \ominus 6,50)$, ainda que ligeiramente inferiores, apresentaram uma mesma tendencia que os obtidos por PANDE \& SHUKLA 61981$)$ que verificaram os indices de 7,13 6,98, respectivamente, para dietas com ureia e proteina verdadeira. A mesma tendencia também foi observada por METHA 8 SINGHAL (1984) que obti veram valores medios de pH de 6,74 e 6,84 com dietas com farelo de oleaginosa e uréa, respectivamente. Da mesma forma AZIZ \& MIR (1986) substituindo parcialmente a fonte proteica do farelo de algodåo por uréla em dietas para bubalinos, observaram uma elevaça no $\mathrm{pH}$ de 6,9 para 7,0 . 


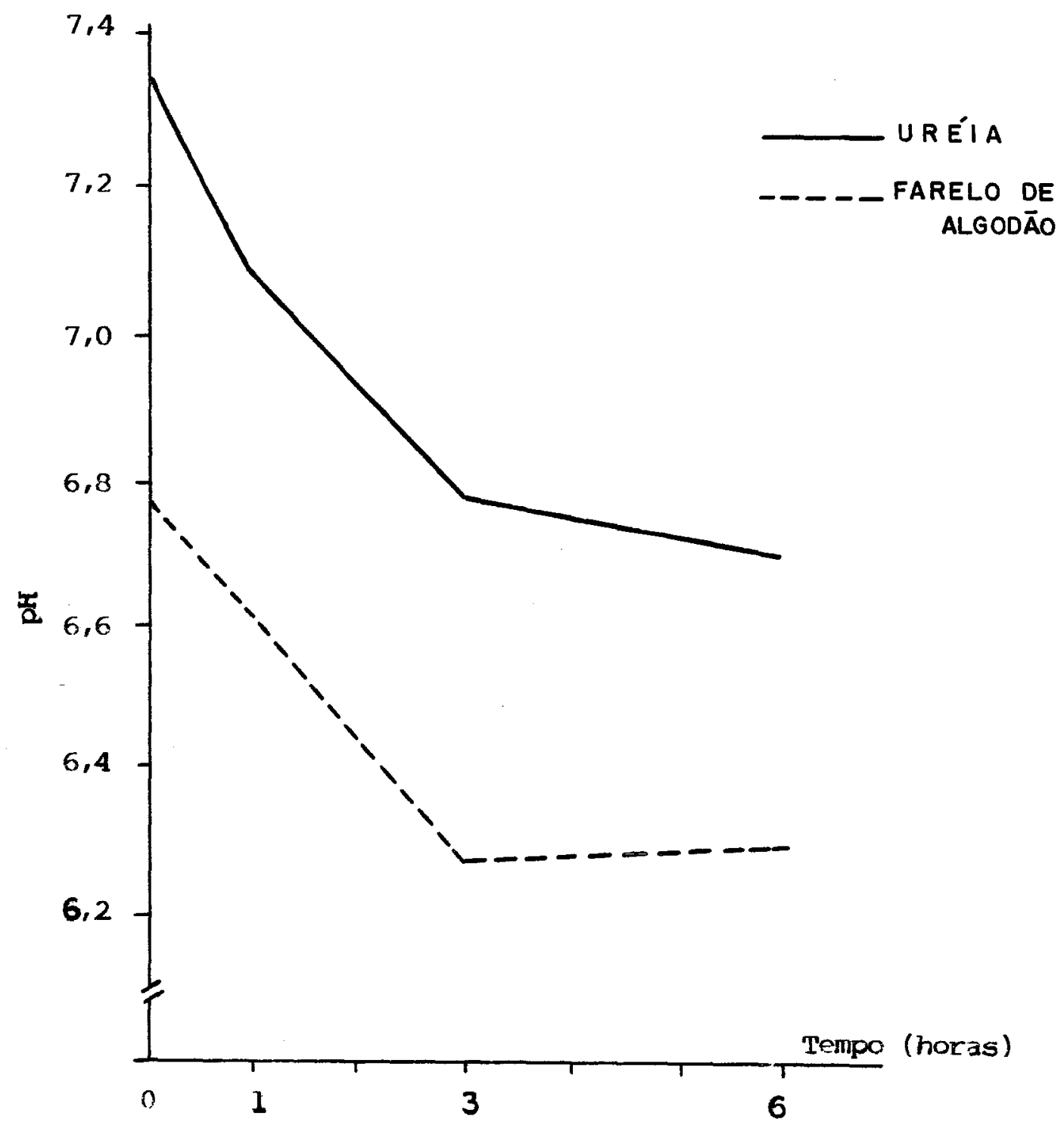

Figura 3. Niveis medios de $\mathrm{pH}$ en liquido ruminal de bubalinos, sob duas dietas em quatro tempos experimentais 


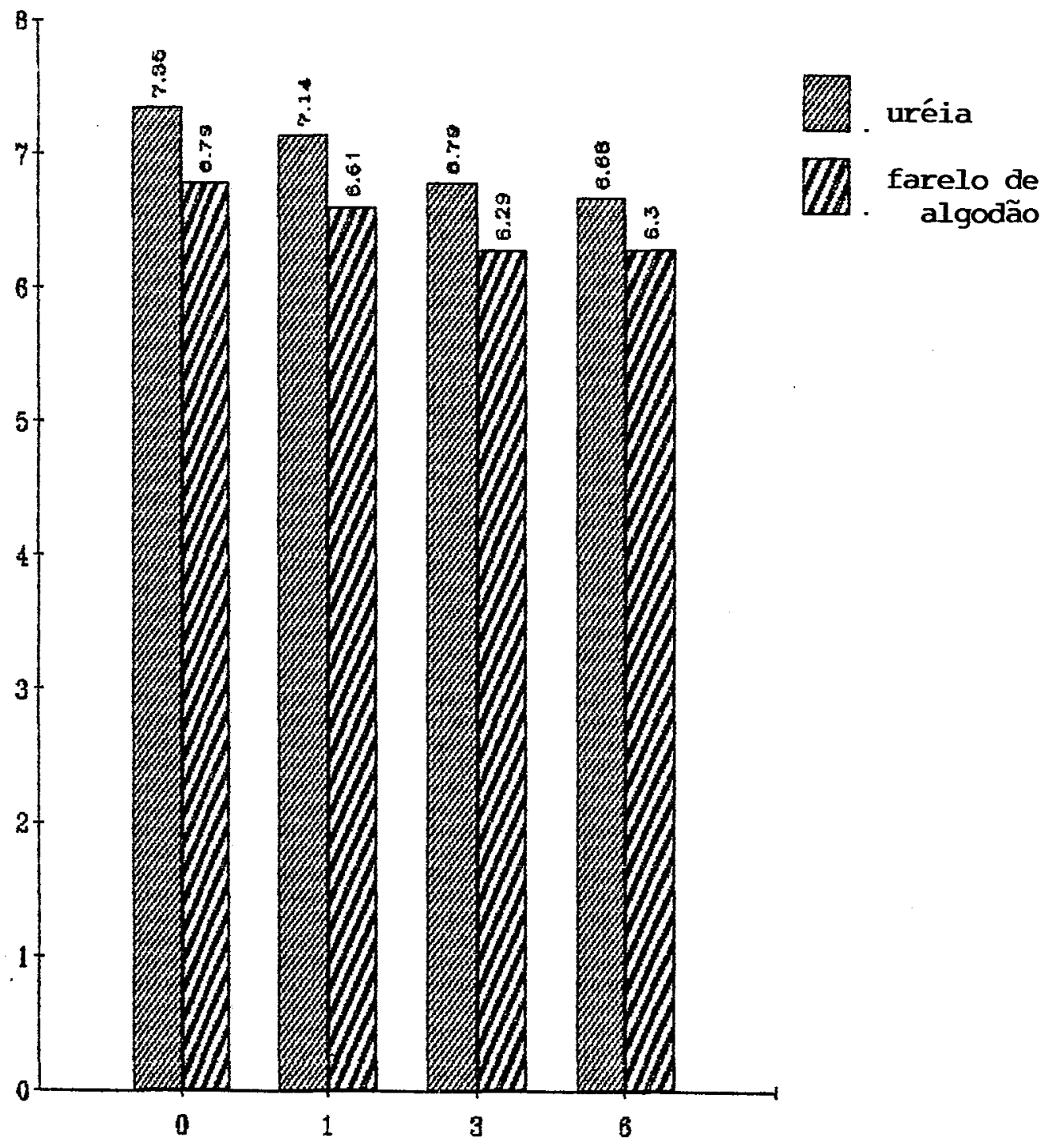

Figura 4. Níveis medios de $p H$ em liquido ruminal de bubalinos, sob duas dietas e em quatro tempos experimentais 
Os maiores indices obtidos nestes trabalhos quando da utilizaço da uréia, foram atribuidos a maior concentraçăo ruminal de N-NHa. Entretanto, a presente pesquisa não permitiu detectar diferenças significativas neste parâmetro (Tabela 2$)$, ainda que houvesse ocorrido uma leve tendéncia a uma maior concentração de $\mathrm{N}-\mathrm{NH3}$ na dieta contendo a ureia. Assim sendo, as variaçoses ocorridas no pH poderiam ser atribuidas a certos fatores não controlados na presente pesquisa, como tempo de ruminaçăo, tamanho de particula e fibrosidade da dieta, conforme indicacão de MCDONALD et ai i $(1975)$, ANNISON \& LEYIS (1966) $P$ PONTES $(1981)$

Considerando a Tabela 4 as Figuras $2 e 3$, verifica-se que o pH apresentou variaçBes decrescentes e estatisticamente significativas $(P<0,05)$ para os tres primeiros tempos, sendo os dois ultimos semelhantes, com os valores médios de 7,$07 ; 6,88 ; 6,54$ e 6,49 , respectivamente, para os tempos de amostragem $0,1,3 e 0$.

os valores mais baixos de $\mathrm{pH}$ registrados ocorreram 3 horas após a alimentaçăo $(P<0,05)$ a semelhança dos resultados de PANDE \& SHUKLA (1981), que trabal hando com bubalinos observaram reduçbes no $\mathrm{pH}$ de 2 a 3 horas após a ingestão de alimentos. Por outro lado, os valores mais altos de $\mathrm{pH}(P<0,05)$ foram observados no tempo 0 , correspondente ao jejum, fato este tambem observado por KOLB (1984) e LAVEZZO (1986). 


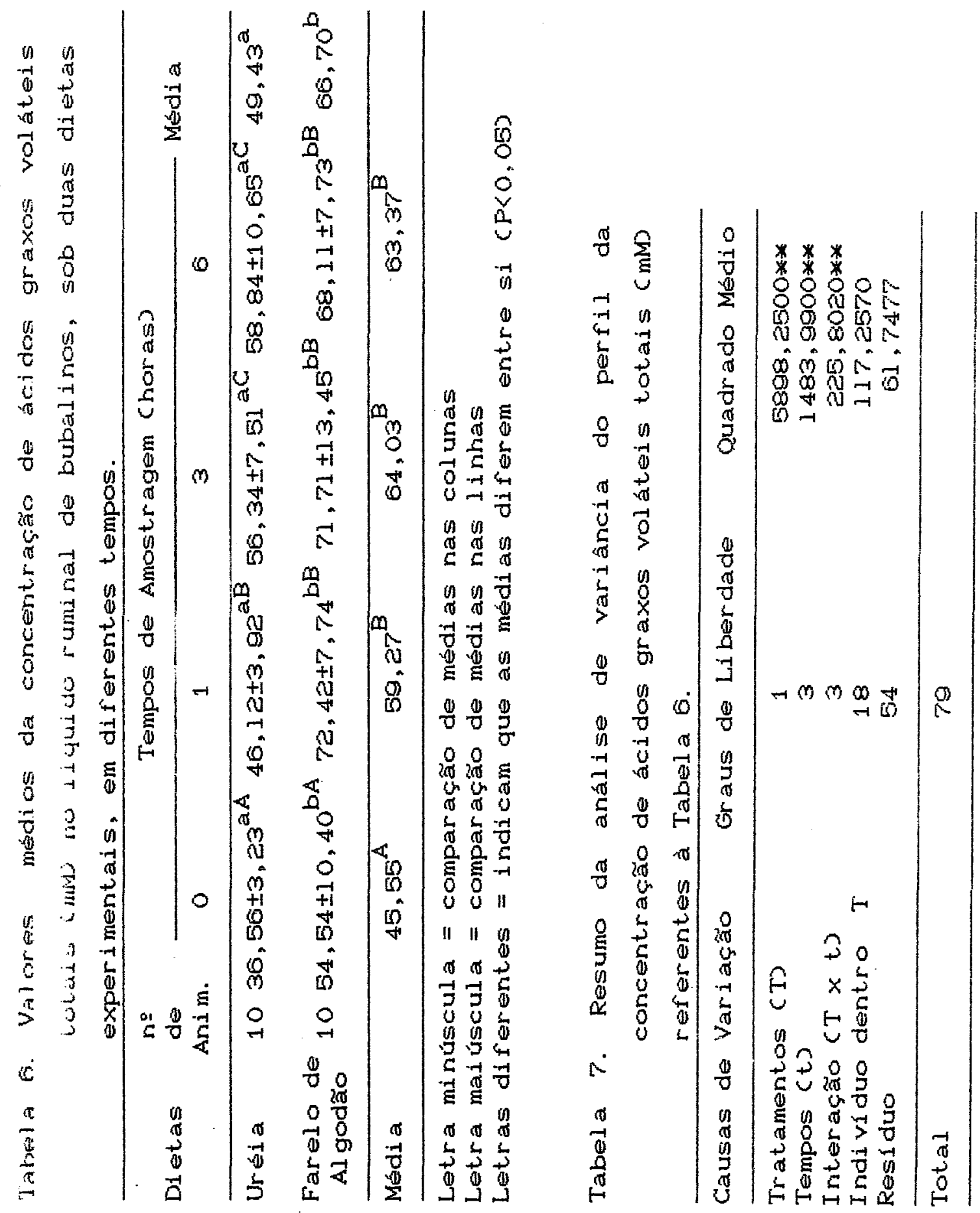


44

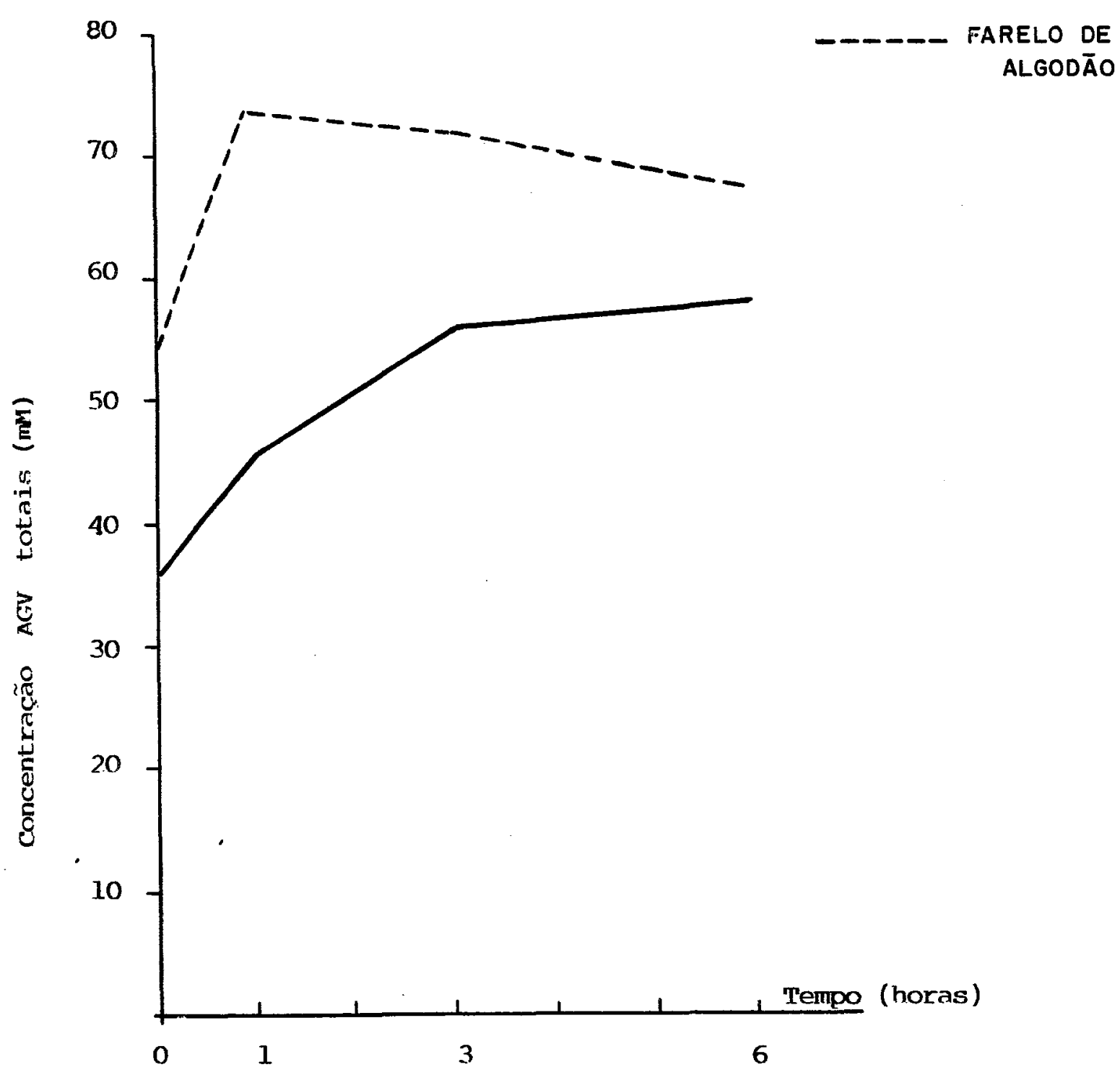

Figura 5. Niveis médios de acido graxos voláteis em liquido ruminal de bubalinos, sob duas dietas em quatro tempos experimentais 


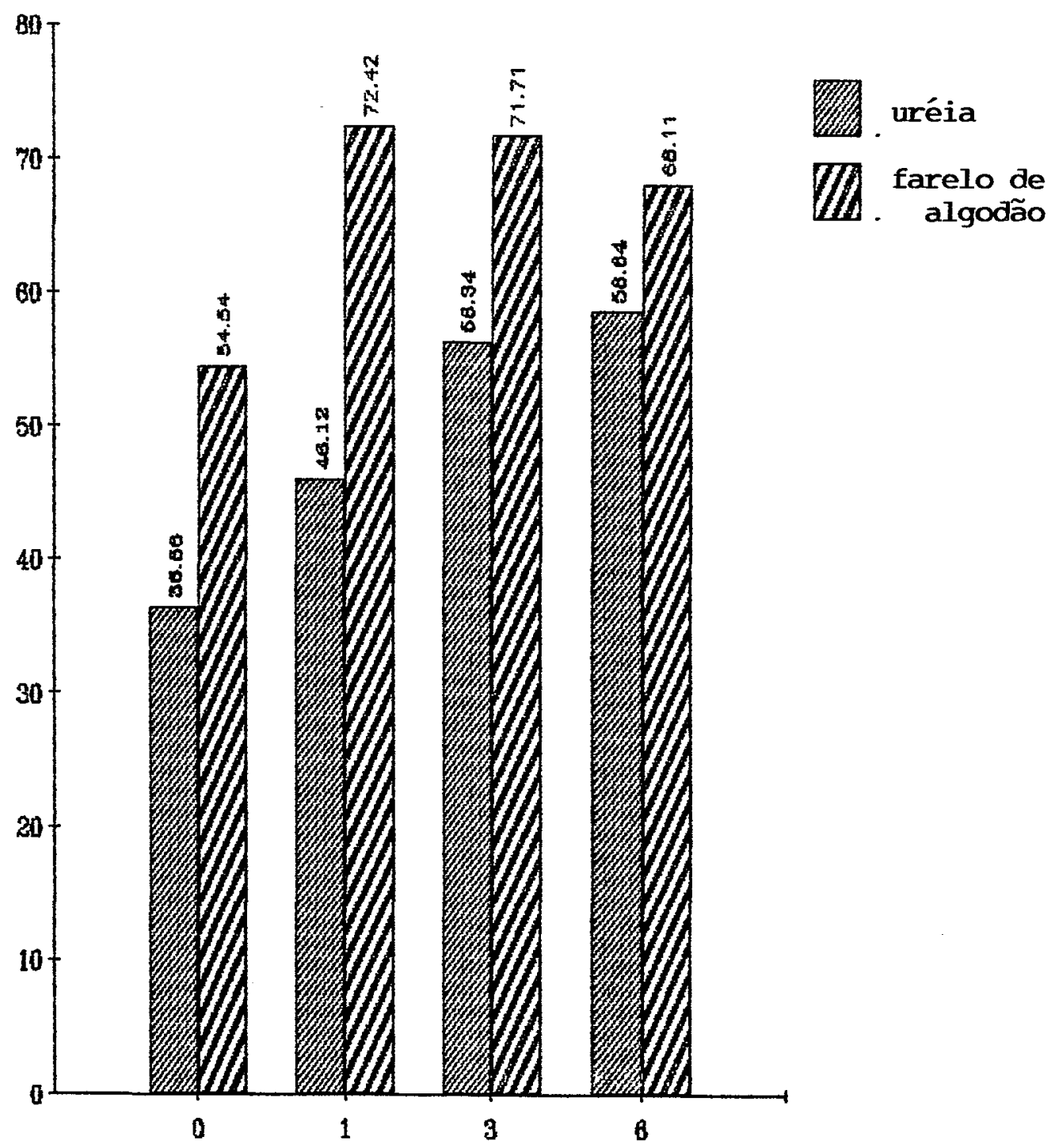

Figura 6. Niveis médios de ácido graxos volateis em 1 iquido ruminal de bubalinos, sob duas dietas e em quatro tempos experimentais 
os valores mais baixos no $\mathrm{pH}$ normalmente indicam concentraçoes mais altas nos ácidos orgânicos. Tal fato parece ter ocorrido na presente pesquisa pois, independente das dietas, a maior produção de ácido propiónico CP < 0,05) ocorreu coincidentemente 3 horas apos a alimentaçå. Por outro lado, o maior indice $p H(P<0,05)$ observado no tempo o cjejum, poderia ser atribuido às baixas concentraçós de ácidos organicos, associados ao efeito tamponante da saliva CPONTES, 1981 .

Nas tabelas $6,8,10$ e 12 são apresentados os valores médios das concentraç̧es molares dos acidos graxos volateis totais, acido acetico, acido propiónico e acido butirico respectivamente, cujos valores estão ilustrados nas Figuras 5 e $6 ; 7$ e $8 ; 9$ e $10 ; 11$ e 12. Nas Tabelas $7,9,11$ - 13 encontram-se as análises de variáncia referentes às Tabelas 6, 8, $10 € 12$. 


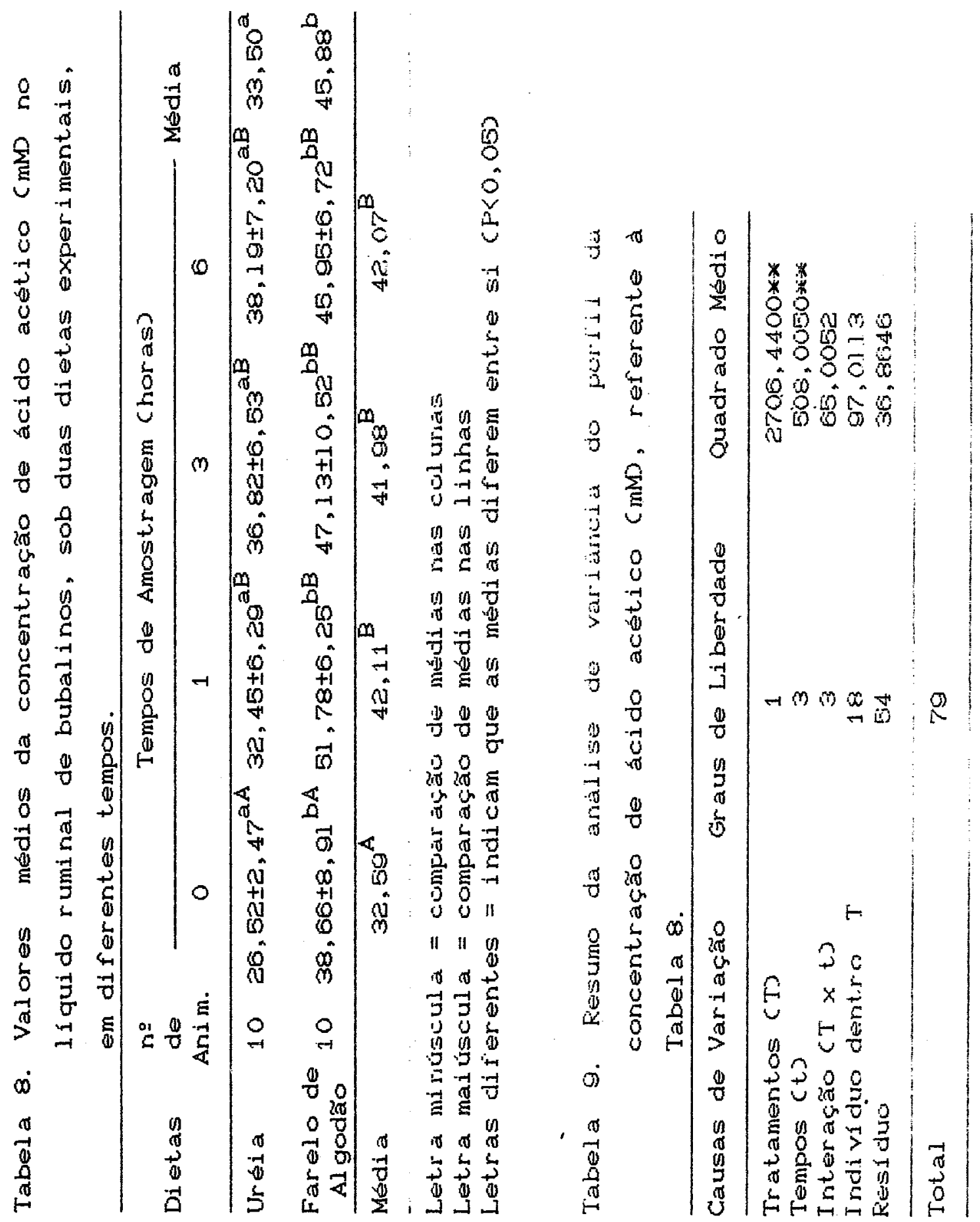




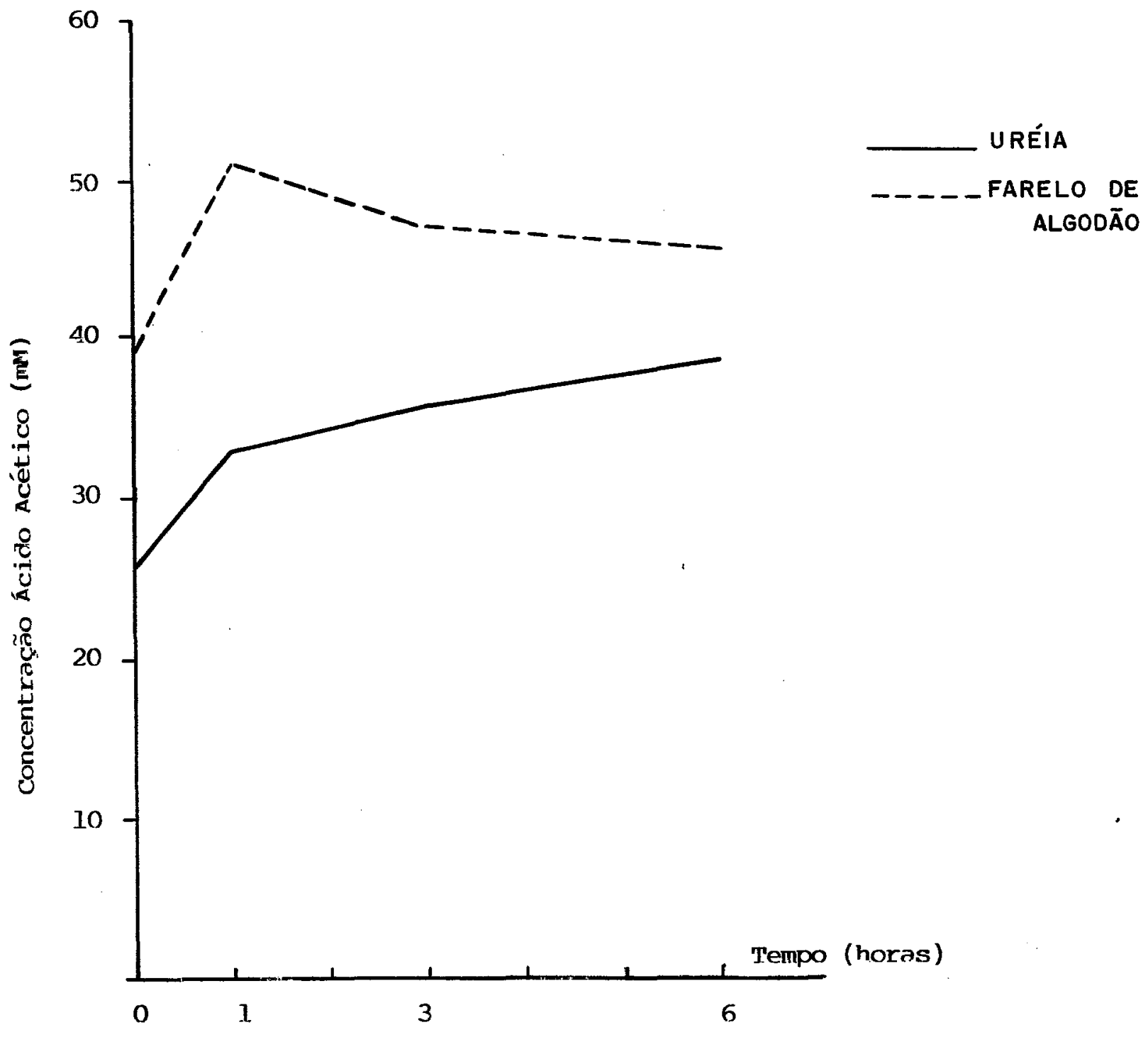

Figura 7. Niveis médios de acido acetico em liquido ruminal de bubalinos, sob duas dietas $\theta$ em quatro tempos experimentais. 


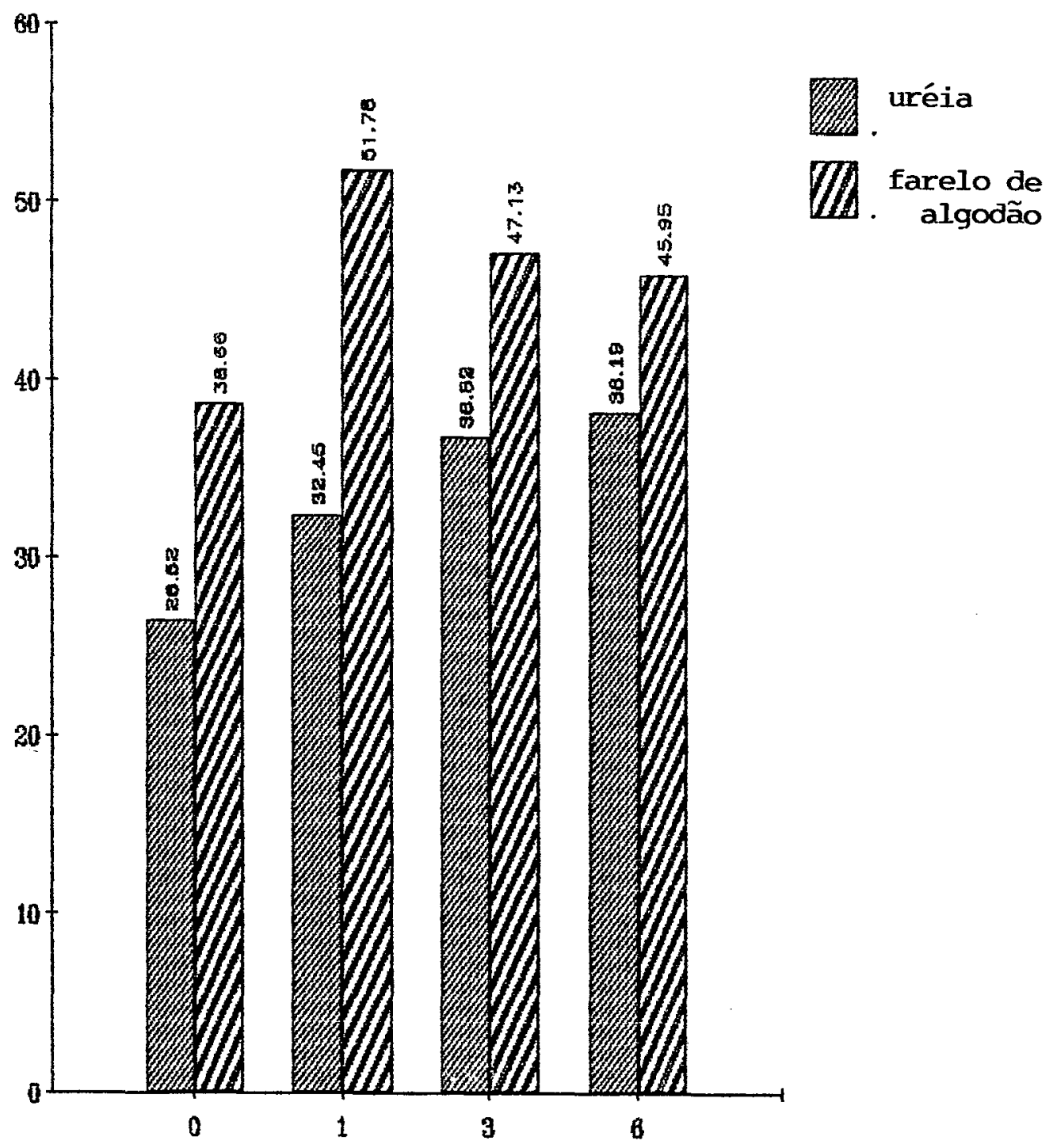

Figura 8. Niveis médios de acido acetico em liquido ruminal de bubalinos, sob duas dietas e em quatro tempos experimentais. 


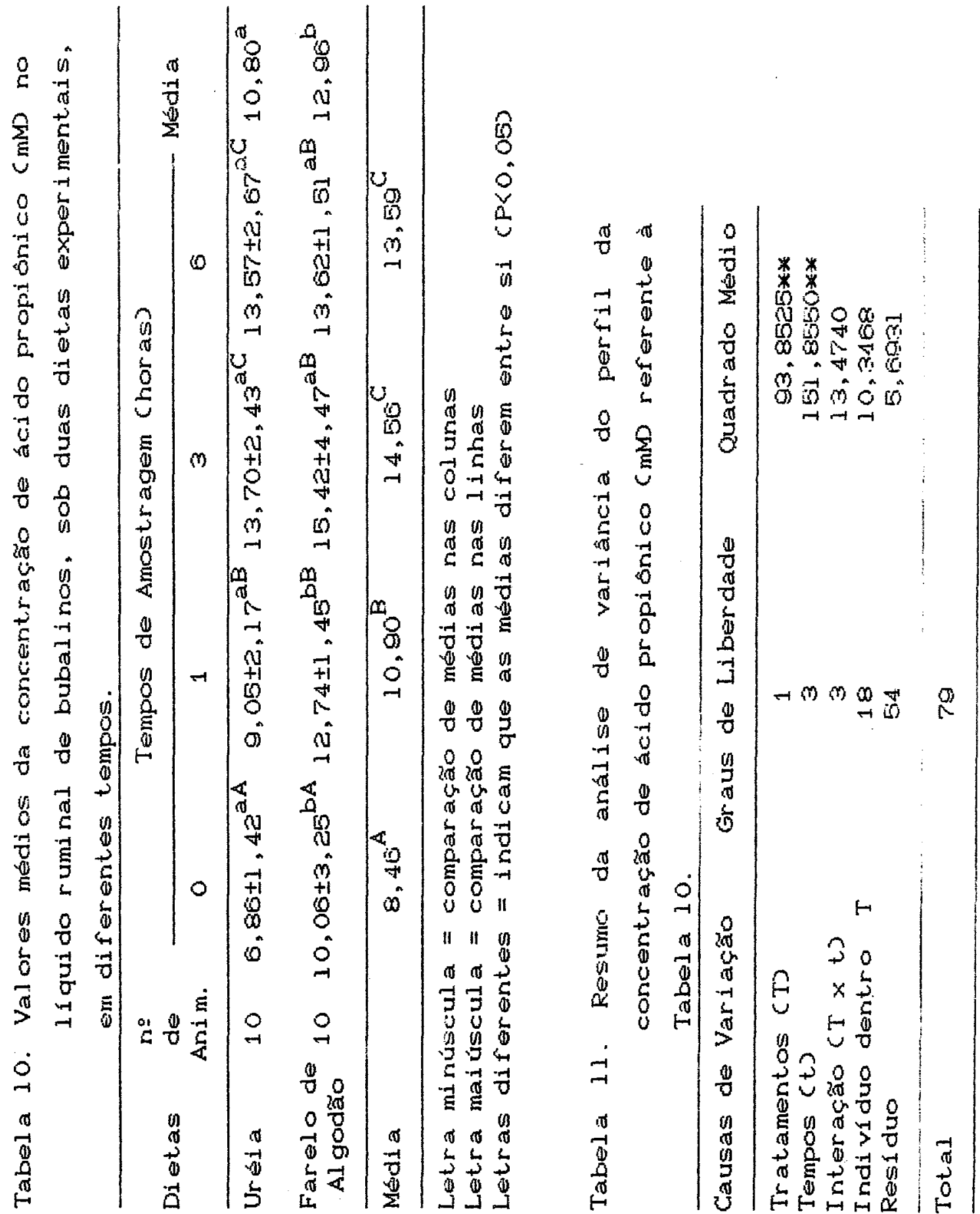




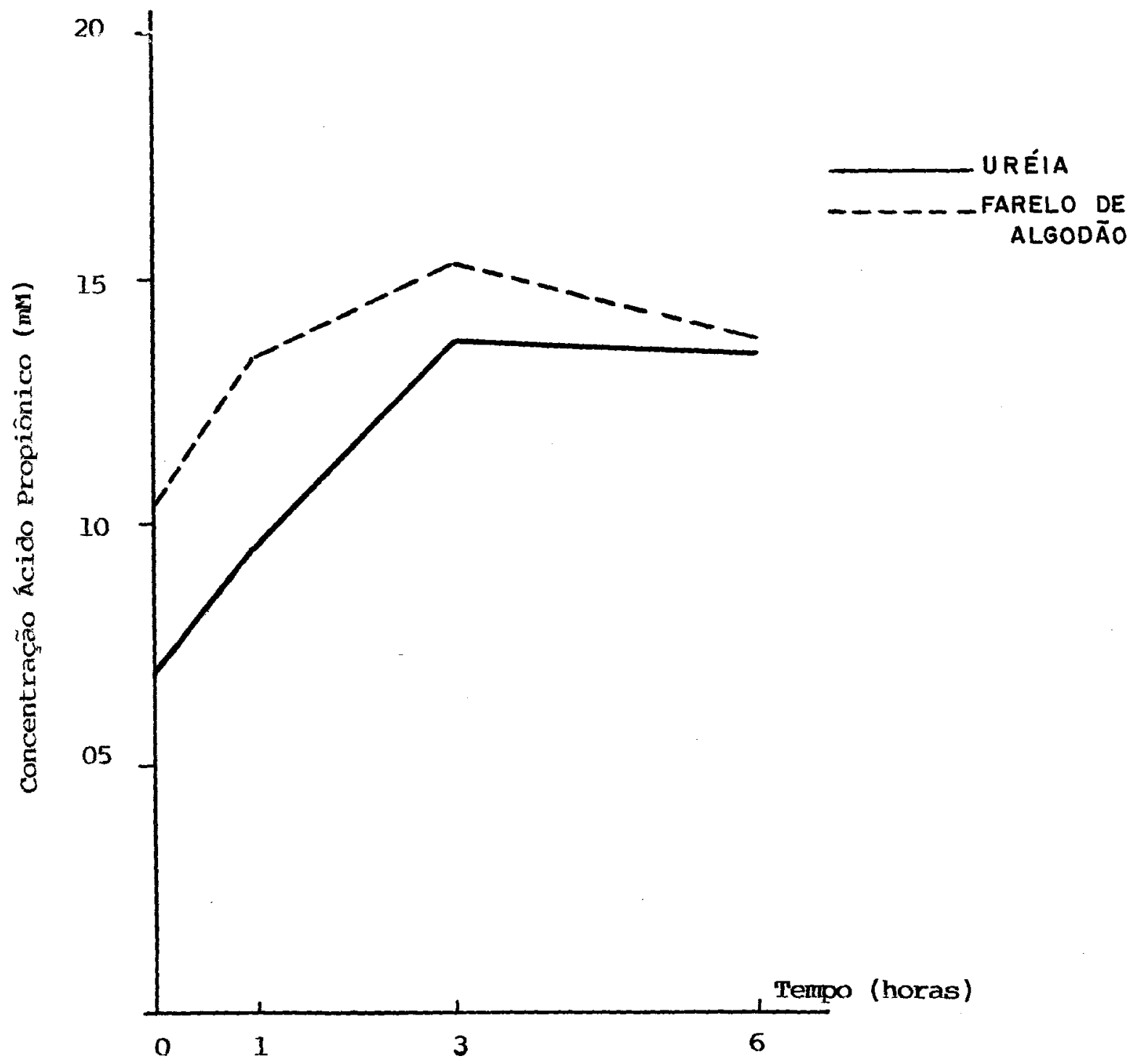

Figura $\theta$. N1veis medios de acido propionico em liquido ruminal de bubalinos, sob duas dietas e em quatro tempos experimentais 


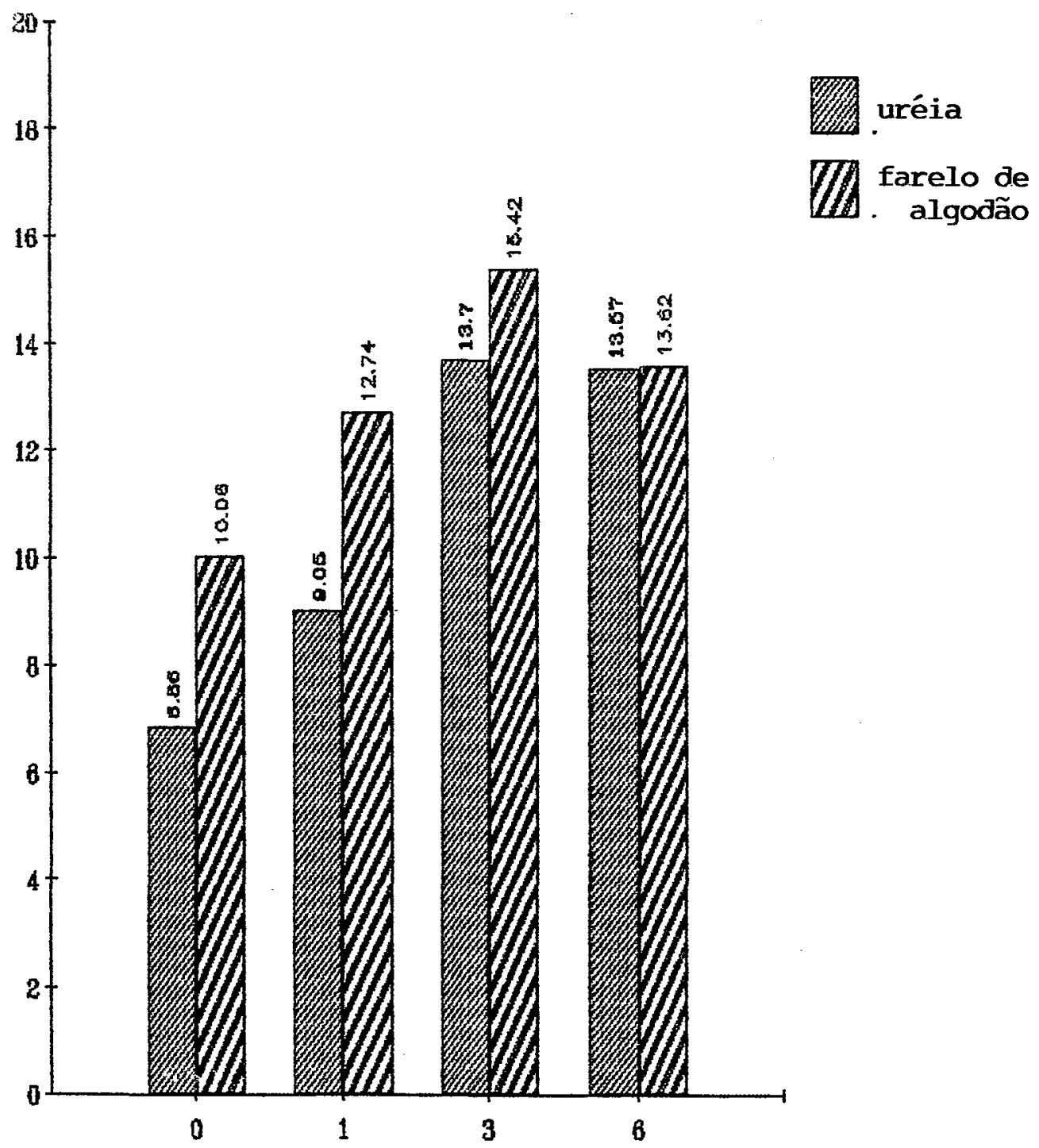

Figura 10. Niveis médios de ácido propionico em liquido ruminal de bubalinos, sob duas dietas e em quatro tempos experimentais 


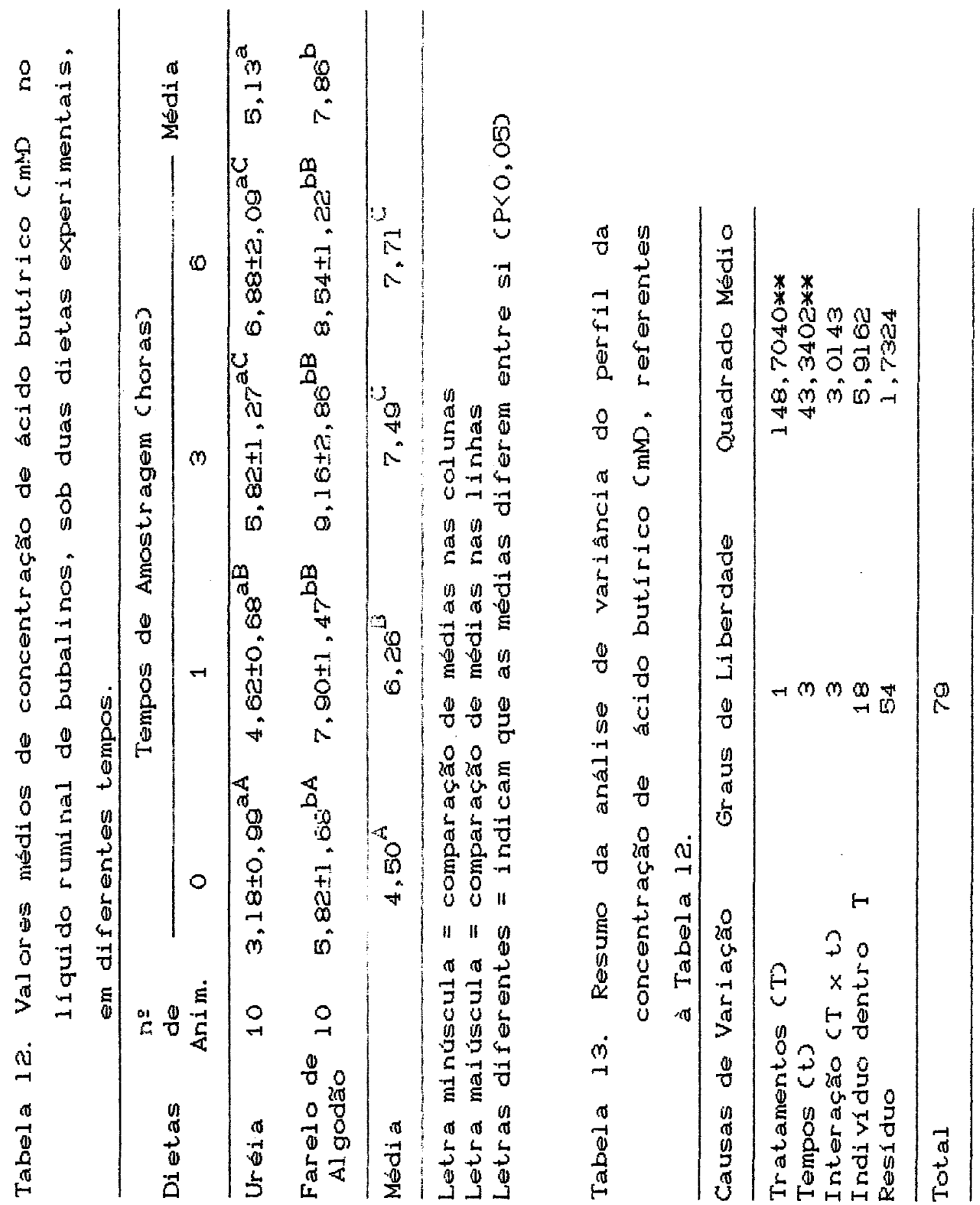




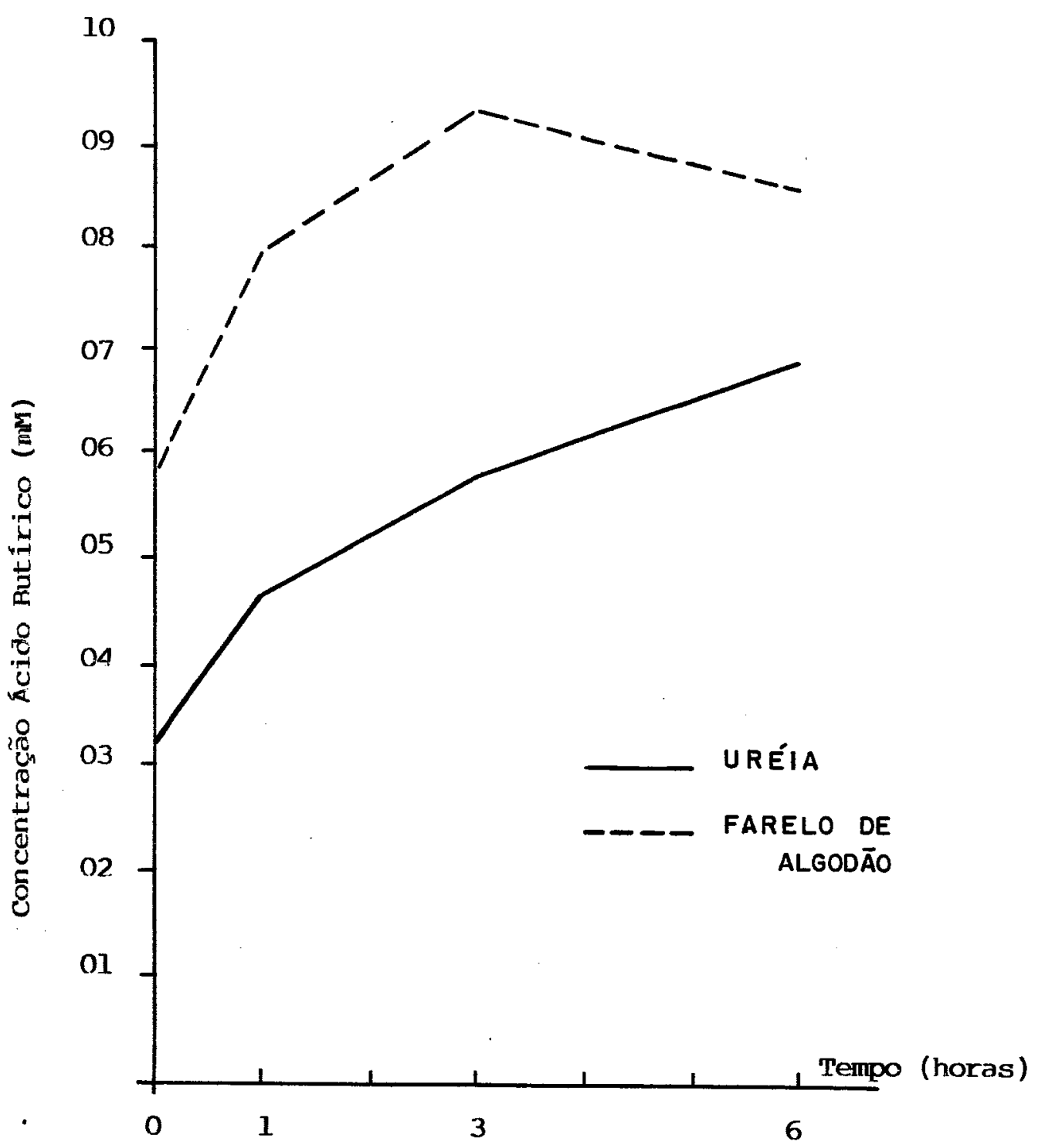

Figura 11. Niveis medios de acido butírico em liquido ruminal de bubalinos, sob duas dietas e em quatro tempos experimentais 


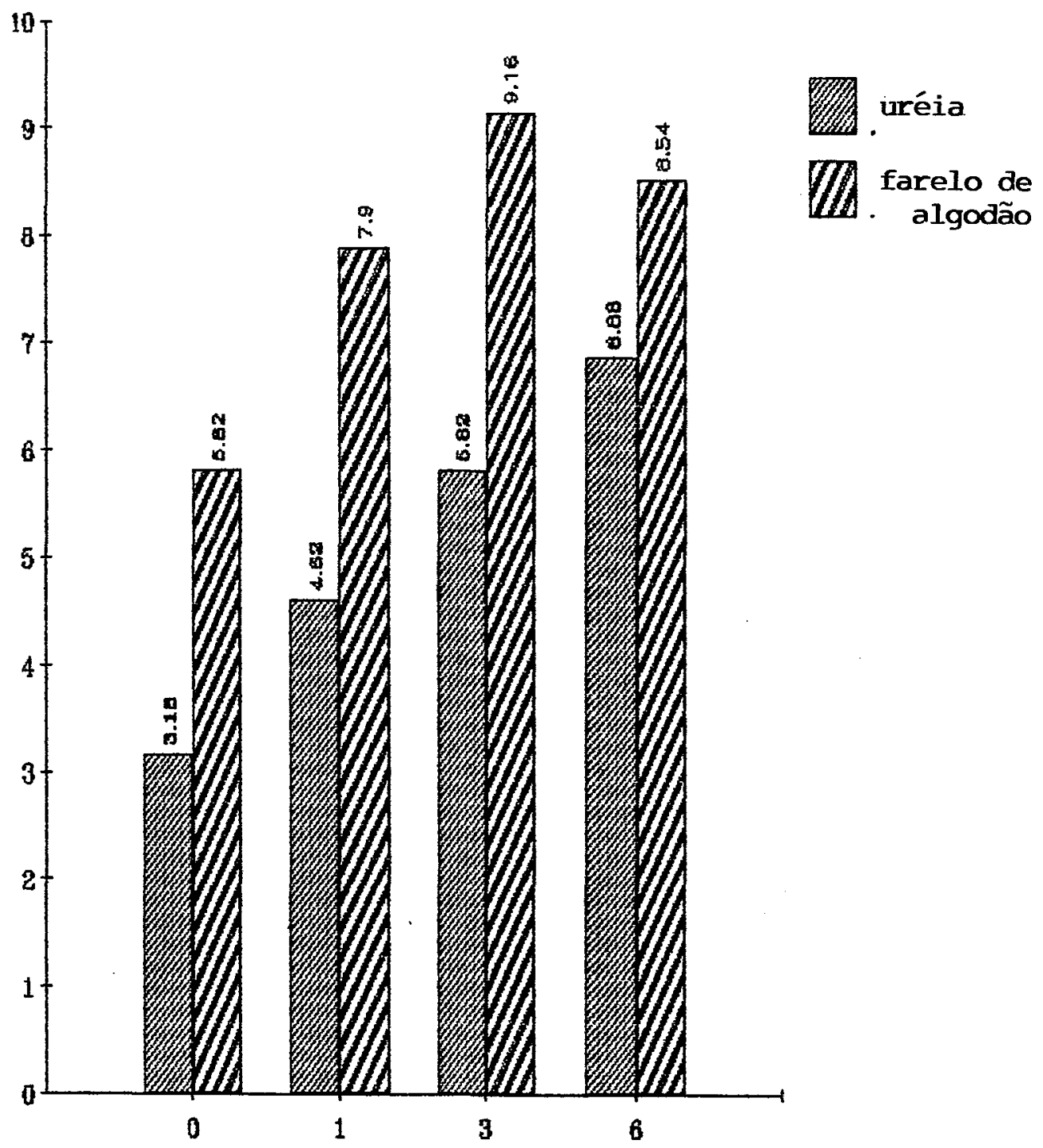

Figura 12. Niveis médios de acido butirico em 1 iquido ruminal de bubalinos, sob duas dietas e em quatro tempos experimentais 
Atraves destas Tabelas e Figuras observa-se que as dietas com ureia e farelo de algodão apresentam diferenças estatisticamente significativas entre si $(P<0,05)$, no tocante aos teores medios de AGVs totais 649,42 - 66,70 $\mathrm{mM}$; ácido acetico $\mathrm{C33,50}$ - 45,88mM; ácido propionico 610,80 e $12,96 \mathrm{mM}$ e acido butírico $\mathrm{C5}, 13$ e 7,86 mD. A analise de variancia mostrou haver tendéncia a uma interaça significativa $C P<0,05)$ entre as dietas, com relação à concentração de AGV totais, indicando que os perfis das dietas não são semelhantes ao longo do tempo. Tal interaça nå foi observada quando os acidos volateis foram analisados separadamente, indicando uma similaridade da curva de concentração entre as dietas nos vários tempos experimentais.

PANDE \& SHUKLA (1981) trabalhando com ursia e outra fonte proteica, observaram uma menor concentração de AGV totais na dieta contendo uréia, fato este observado também por KAPOOR et alii (1987), quando estes arraçoaram bubalinos com dietas contendo ou năo uréia, o que está de acordo com os dados apresentados nesta pesquisa. Por outro lado, LANGAR et alii (1984) fornecendo dietas com e sem ureia a bubalinos, não obtiveram diferenças significativas entre as dietas. Da mesma forma, FREITAG et ai i (1968) também não observaram diferenças significativas entre os parámetros AGVs totais e os acidos acético, propionicoe butirico, entre raços formuladas com diferentes niveis e 
fontes proteicas, incluindo a ureia.

LAVEZZO (1986) trabal hando com dietas contendo duas fontes proteicas, levedura e farelo de algodaro, obteve os teores medios de AGVs totais 677,03 e $74,83 \mathrm{mM}$, ácido acético $(48,86 \odot 51,39 \mathrm{mM}$, acido propionico $(15,40 \%$ $13,70 \mathrm{mM}$ ácido butírico 610,79 e $7,93 \mathrm{mM}$. Comparativamente, estes últimos dados, em relacão aos obtidos na presente pesquisa, foram menores em todos os parametros, entretanto, quando comparou-se somente as duas dietas, de ambas as pesquisas formuladas com farelo de algodão verificou-se uma certa proximidade de valores notadamente para os ácidos propionico e butirico.

Os mais altos valores encontrados na presente pesquisa para as concentraçes de AGVs totais, acidos acetico, propionico e butirico na dieta com farelo de algodå em relação a uréia, talvez possam ser atribuidos ao maior valor nutritivo do farelo de algodão, uma vez que, com a introduça da uréia os microrganismos do rúmen foram privados de significativa parcela de nutrientes, notadamente de isoácidos oriundos dos aminoacidos valina, leucina e isoleucina, encontrados no farelo CEL SHASLY, 1952), fato este que favorece a maior produçăo de ácido acético. 0 incremento na produçăo do ácido butirico pode ser atribuido tamberm a uma elevação da concentração do acido acetico, pois, segundo CHURCH (1979), 40 a $80 \%$ do ácido butirico presente no rúmen $\&$ devido a atuaça de microrganismos que 
fazem a condensação de dois moles de ácido acético para produzir um mol de acido butirico.

Na presente pesquisa, apesar dos valores medios da concentraçăo de acido propiônico terem sido estatisticamente superiores $C P<0,05$ para a dieta com farelo de algodão, cabe ressaltar que esta diferença não se manteve apos tres horas decorridas da alimentação $(P<0,05)$, tempo no qual ocorreram, para as duas dietas, os picos de maior produção de ácido propiónico, coincidentemente com o pico de mais baixo pH. E bastante conhecido que a produça de acido propionico estimulada pelo abaixamento do pH CBALCH \& ROWLAND, 1957), atraves do favorecimento da. proliferação de microrganismos que fazem sua sintese.

Analisando-se as Tabelas $6,8,10 \odot 12$, $e$ as Figuras 5, 6,7 e observa-se um comportamento estatisticamente diferente (P<O,O5) das dietas experimentais, nos tempos de coletas estudados, para os parametros AGV totais, ácido acético, ácido propionico e ácido butırico.

Assim sendo, quando se considera a dieta com uréia, observa-se que a máxima concentração de produção CP< $0,05)$ de AGV totais 656,34 e $58,46 \mathrm{mM}$, acido acetico 636,82 e 38,19 mM, ácido propiónico 613,70 e $13,57 \mathrm{mM}$ e ácido butirico 65,82 e $6,88 \mathrm{~mW}$ ocorreu de 3 a 6 horas apos a al iment ação.

Na dieta com farelo de algodão, a máxima 
produção de AGV totais $(72,42 ; 71,71$ e $68,11 \mathrm{mM}$, acido acetico $(51,78 ; 47,13$-45,95 mM ; acido propionico 12,74 ; 15,42e $13,62 \mathrm{mM}$ e ácido butirico 67,$90 ; 9,16$ e 8,54 mM, ocorreu de 1 a 6 horas após a alimentação.

Resultados semel hantes foram obtidos por PANDE \& SHUKLA (1981), os quais também obtiveram a máxima produção de AGV totais 3 horas após a alimentaçăo com uréia, $\theta$ tambem por BHATIA et ali $i$ (1980), que observaram o pico de produça de AGV 4 horas após a ingestao da dieta contendo ureia.

Por outro lado, a obtença de picos de produção de AGV 1 hora após a ingestão da dieta contendo farelo de algodão, talvez se deva ao maior valor nutritivo da fonte de proteina verdadeira CKAPOOR et alii, 1987), que propicia uma maior quantidade de aminoácidos precursores de isoácidos (KOLB, 1984), os quais estimulam o desenvolvimento de bactérias (HUNGATE, 1966 ).

ANNISON \& LEWIS (1966) observaram que as proteinas verdadeiras săo de baixa degradabilidade, pois sofrem inicialmente a protedise e a seguir a desaminação. Isto poderia explicar em parte as maiores taxas de $\mathrm{N}-\mathrm{NH}$ (14,61 mg/dl) obtidas no tempo o para a dieta contendo farelo de algodão, superiores $C P<0,05>$ a $9,36 \mathrm{mg} / \mathrm{dl}$ para a dieta contendo uréia. Isto implicaria em um maior número de bacterias em função do substrato nitrogenado existente, explicando assim o pico de produção de AGV 1 hora após a alimentação. Já com relação a dieta contendo uréia, a 
concentração maior de $\mathrm{N}-\mathrm{NH3}$ ocorreu somente 1 hora apos a ingeståo de alimento, o que retardou o pico de producão de AGV para 3 horas apos a alimentação.

Estas argumentaços encontram suporte nas observaços de LAVEZZO (1986), que obteve picos de produça de amonia $e$ a 4 horas apos a alimentação, e dos ácidos graxos volateis (ácido butirico) somente 4 a 6 horas, como decorrencia da degradação da proteina ocorrida inicialmente. 


\section{CONCLUSOES}

Nas condiçes do presente trabal ho as seguintes conclusobes podem ser apontadas:

1. A substituiço parcial da proteina do farelo de algodão por ureia é viável ao nível de $1 \%$ da dieta, uma vez que, a análise dos parametros ruminais demonstrou a existencia de condiçós adequadas para o desenvolvimento dos microrganismos do rúmen em ambas as dietas. A sua utilização fica na dependencia da rel ação custo/benef 1 cio.

2. 0 uso da dieta contendo uréia resultou em maiores indices de pH em relação ao uso da dieta contendo somente farelo de algodăo como a principal fonte de proteinas, porem, em nemhum dos tempos estudados atingiu o nivel critico que potêncializa a passagem 
da amonia ruminal para o sistema circulatório, evidenciando que o nivel de $1 \%$ uréia na ração em substituição parcial do farelo de algodão, não acarreta riscos de intoxicasão.

3. A maior concentração de nitrogenio amoniacal registrada, ocorreu 1 hora após a ingestao da dieta contendo ureia entre 1 a 3 horas naquela contendo somente farelo de algodão $e$ e devida a mais lenta degradabilidade desta última, favorecendo uma atividade microbiana mais constante, caracterizada pelas maiores taxas de produção de ácidos graxos volateis, inclusive no momento anterior ao consumo de alimentos.

4. A dieta contendo exclusivamente farelo de algodão, como única fonte suplementar de proteina, apresentou padröes de fermentaça ruminal superiores aquela contendo uréia, fato este alicergado nas maiores concentraç̧os de ácidos graxos volateis totais, ácido acético, ácido propiónico acido butirico. Esta condiça qualifica a proteina verdadeira como substrato mais eficiente que o nitrogénio não proteico para o desenvolvimento dos microrganismos ruminais. 


\section{REFERENCI AS BIBLIOGRAFICAS}

AHRAR, M. \& SCHINGOETHE, D.J. Heat-treated soybean meal as protein supplement for lactating cows. J. Dairy Sci., Champaign, $6 \mathrm{e}(6): 932-40,1979$.

ANNISON, E.F. \& LEWIS, D. El Metabolismo en el Rumen. Mexico, Union Tipografica Editorial Hispano Americana, 1966. 200p.

AZIZ, T. \& MIR, F.A. Studies on rumen physiology of buffalo bulls receiving different nitrogen sources with sugar cane pith. Pakistan Veterinary Journal, Qi12:11-14, 1986. In: Nutrition Abstracts and Reviews, $57(1): 32,1986$.

BALCH, D. A. \& ROWLAND, S.J. Volatile fatty acids and latic acid in the rumen of dairy cows receiving a variety of diets. Br. I. Nutr., Cambridge, 1163): 288-98, 1957. 
BATH, I.H. \& ROOK, J.A.F. The evaluation of cattle foods and diets in terms of the ruminal concentration of volatile fatty acids. I. The effect of level of intake, frequency of feeding, the ratio of hay concentrates in the diet and of supplementary feeds. J. agric. Sci., Cambridge, $\underline{61}(3): 341-8,1963$.

BATH, I.H. \& ROOK, J.A.F. The evaluation of cattle foods and diets in terms of the ruminal concentration of volatile fatty acids. II. Roughages and succulents. J. agric. Sci. $\underline{\text { Stic }}(1): 67-75,1965$.

BHATIA, K.P. \& SINGH, R. Rumen metabolic profile as influenced by dietary non-protein nitrogen and soluble carbohydrates. Indian J. Anim. Sci., New Delhi, 50( 1$): 16-20,1980$.

BLOOMFIELD, R. A. Kinetics of urea metabolism in sheep. I. Anim. Sci. 19: 1248, 1960.

BLOOMFIELD, R. A. ; KEARLEY, E. O. ; CREACH, D. O. ; MUHRER, M. E. Ruminal $\mathrm{pH}$ and absorption of ammonia and VFA. I. anim. Sci. . Albany, 巳ę( 3$): 833,1963$.

BUCHANAN-SMITH, J.G. \& YAO, Y.T. Non-protein nitrogen in corn silage: a practical characterization in the rumen 
and effect upon digestibility and retention of nitrogen in lambs. Can. I. Anim. Sci. Ottawa, 586081-90, 1978.

BRYANT, M.P. The nitrogen metabolism of pure cultures of ruminal bacteria. U.S.D.A., A.R.S. 44-92, 1961.

BURCHALL, J.J.; NIEDERMAN, R. A.; WOLIN, M.J. Amino group formation and glutamate synthesis in Streptococcus bovis. I. Bacteriol. , 88: $1038,1964$.

CHURCH, D.C. Digestive physiology and nutrition of ruminants. Vol. 1 - Digestive Physiology. 3ed. Oxford Press Inc., 1979. 350p.

COCKRILL, H.R. The husbandry and health of the domestic buffalo. Rome, Food and Agriculture Organization of the United Nations, $1974.993 p$.

EDHARDS, J.S. \& BARTLEY, E.E. Soybean meal or starea for microbial protein synthesis or milk production with rations above thirteen percent natural protein. J. Dairy Sci. , Champaign, 트: 732, 1979.

EL-SHAZLY, K. Degradation of protein in the rumen of the sheep. 1. Some volatile fatty acids, including branchedchain isomers, found in vivo. Biochem, I., 
Cambridge, $51(5): 640-53,1952$.

ERFLE, J.D.; BOILA, R. J.; TEATHER, R.M.; MAHADEVAN, S. ; SAVER, F.D. Effect of $\mathrm{pH}$ on fermentation characteristics and protein degradation by rumen microorganisms in vitro. I. Dairy Sci., Champaign, 65: 1457-64, 1982.

ERHIN, E.S.; MARCO, G.J.; EMERY, E.M. Volatile fatty acid analysis of blood and rumen fluid by gas chromatography. J. Dairy Sci., Champaign, 44(9):1768-71, 1961 .

FOLDAGER, J. Protein requirement and non protein nitrogen for high producing cow in early lactation. East Lansing, 1977. (Ph.D - Michigan State University).

FREITAG, R.R.; SMITH, W.H.; BEESON, W.M. Factors related to the utilization of urea vs. protein-nitrogen supplemented diets by the ruminant. I. Anim. Sci., Albany, 27(2) : 478-83, 1968.

GRIFFITHS, T.W. \& BATH, I.H. Effects of energy and nit.ogen supplementation of silage diets on rumen fermentation in fistulated heifers. J. agric. Sci., Cambridge, 80(1): $89-95,1973$. 
HOFIREK, B.A. Simple method for collecting of the rumen liquor of cattle for diagnostic purpose. Vet. Med., Praha, 15(3):75-85, 1970.

HUBER, J.T. Nonprotein nitrogen replacement of dietary protein-leaflet. Seminar at ESALQ in Piracicaba, SP, Brazil. 1984.

HUNGATE, R.E. The rumen and its Microbes. New York, Academic Press, 1966. 533p.

ICHHPONANI, J.S. \& SIDHU, G.S. Biochemical process in the rumen. I. The production of volatile fatty acids in the rumen of cattle and buffalo feed on green berseen and wheat straw. Indian J. Vet. Sci., Madra, 3563):265, 1965.

ICHHPONANI, J.S.; MAKKAR, G.S.; SIDHU, G.S. Studies on the, biochemical processes in the rumen. IV. Product, on of volatile fatty acids CVFA in vitro by rumen microorganisms obtained from the ruminar of tre buffalo and cattle. Indian J. Anim. Sci.. New Delhi, $39(3): 201-6,1968$.

JONES, G.A.; MAC. LEOD, R.A.; BLACKWOOD, A.C. Ureolytic rumen bacteria. II. Effect of inorganie ions on urease 
activity. Can I. Microbiol., 10: $379,1964$.

JORDAN, E.R. \& SHANSON, L. W. Effect of crude protein on reproductive efficience serum total protein and albumin in the high producing dairy cow. J. Dairy Sci., 62( 1$): 58-63,1979$.

KANG-MEZNARICH, J.H. ; BRODERICK, G.A. Effect of incremental urea supplementation on ruminal ammonia concentration and bacterial protein formation. I. Anim. Sci., Albany, 51: $422-31,1981$.

KAPOOR, P.D.; NANGRA, O.P.; GUPTA, M. Studies on some of the rumen and blood metabolites on isonitrogenous urea/molasses supplemented ration in buffalo calves. Indian Vet. I. Madras, $64(8): 669-73,1987$.

KOLB, E. Fisiologia Veterinária. 4a. ed. Rio de Janeiro, Editora Guanabara Koogan S A, 1984. 61 Zp.

KULASEK, 6 . A micromethod for determination of urea in plasma, whole blood and blood cells using urease and phenol reagent. Pol. Arch. Wet., Marsaw; 15(4):801-10, 1972.

LANGAR, P.N.; MAKKAR, G.S.; EAKSHI, M.P.S. Comparative 
studies on the urea and fibre utilization in buffalo and cattle. Indian J. Anim. Sci., New Delhi, 5465):413-19, 1984.

LAVEZZO, O.E.N.M. Influencia dos metodos de coleta de fluido ruminal sobre os parametros de fermentaça, em bovinos alimentados com diferentes fontes de proteina. Piracicaba, 1986. 167p. CTese - Mestrado, Escola Superior de Agricultura "Luíz de Queiroz" - USPD.

MCDONALD, I. W. The role of ammonia in ruminal digestion of protein. Biochem. I. Cambridge, 51(1):86-90, 1952.

MCDONALD, P.; EDWARDS, R.A.; GREENHALGH, J.F.D. Nutriçăo Animal. Editorial Acribia, Zaragoza, 1975.

MCLAREN, G. A. ; ANDERSON, G.G.; TSAI, L. T.; BARTH, K.M. Level of readily fermentable carbohydrates and adaptation of lambs to al1-urea supplemented rations. I. Nutr. , 87: $331,1965$.

MC NAUGHT, M.L.; OWEN, E.C.; HENRY, K.M.; KON, S.K. The utilization of non-protein nitrogen in the bovine rumen. 8. The nutritive value of the protein of preparations of dried rumen bacteria, rumen protozoa and brewer's yeast for rats. Biochem J., Cambridge, S6(1):151-6, 1954. 
MACHADO, P.F. Valor nutritivo da levedura, residuo da produção de álcool, para vacas em lactação. Săo Paulo, 1983. 110p. CTese - Doutorado - Faculdade de Ciencias Farmacêticas - USPJ.

MAHADEVAN, S.; SAUER, F.D.; ERFLE, J.D.; TEATHER, R.M. ; MORSE, P.M. Changes in ammonia concentration, bacterial counts, $\mathrm{pH}$ and volatile fatty acid concentration in rumen of cows fed alfafa hay or concentrate: urea-corn silage.

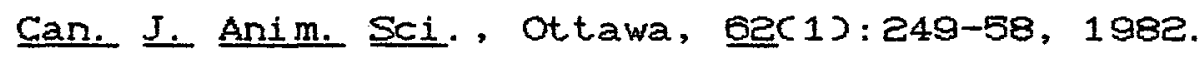

MEHREZ, A.Z.; ORSKOV, E.R.; MCDONALD, I. Rates of rumen fermentation in relation to ammonia concentration. Brit. J. Nutr. , 38: $437,1977$.

MEHTA, R.K. \& SINGHAL, K.K. Effects of pelleting and supplementing urea to agroindustrial byproducts on nutrient utilization and rumen fermentation in buffaloes. Indian I. Anim. Sci., New Deihi, Sif(1):19-24, 1984.

MORRISON, D.F. Multivariate Statistical Methods. New York, Me Graw Hill Book Company, 1967. 338p. 
MOTT, G.O.; QUINN, L.R.; BISSCHOFF, N.V.A.; ROCHA, G.L. Melaço como suplemento energético para novilhos zebu, em pastejo de capim Coloniå com e sem adubo nitrogenado. Pesg. Agropec. Bras., 료 441-59, 1967.

MURDOCK, F.R. \& HODGSON, A.S. Effects of roughage type and texture of milk fat secretion and body weight recovery by lactating dairy cows. J. Dairy Sci. , 62 :505-10, 1979.

NOLAN, J.Y.; NORTON, B. H.; LENG, R.A. Nitrogen cycling in sheep. Proc. Nutr. Soc., London, 3262):93-8, 1973.

NRC Nutrient Requirement of Beef Gattle. National Academy Press, Hashington, DC, $6^{\text {th }}$ revised edition, 1984.

OLTJEN, R..R. ; WILLIAND, E.E. ; SLYTER, L.L. ; RICHARDSON, G. V. Urea versus biuret in a roughage diet for steers. I. Anim, Sci., 29: $816,1969$.

ORSKOV, G.R.; FLATT, W.P.; MOE, P.Y. Fermentation balance approach to estimate extend of fermentation and efficiency of volatile fatty acid formation in ruminants. I. Dairy Sci. , Champaign, 51(1):1429-35, 1968.

PANDE, M.B. \& SHUKLA, P.C. Effect of seeding digestible crude protein levels and urea of rumen liquor nitrogen 
fractions and volatile fatty acids. Indian Vet. I. Madras, $\underline{58(11): 894-900,1981 .}$

PANT, H.G. \& ROY, A. Studies on the rumen microbial activity of buffalo and zebu cattle. Concentration of microorganisms and total and particulate nitrogen in the rumen 1 iquor. Indian J. Anim. Sci., New Delhi, 40(6): $600-609,1970$.

PATHAK, N.N.; SINGH, V.B.; KUMAR, P. ; VERMA, D.N.; RANJHAN, S.K.; SRIVASTAVA, R.V.N. Utilization of urea-molasses liquid diet with restricted intake of wheat straw and intact proteins by adult cattle and buffaloes with special reference to VFA production rates. Indian J, Anim. Sci. , New Del hi, 436 9 : 819-23, 1973.

PIDGEN, W.J. Effect of physical and chemical processing non protein nitrogen supplementation on utilization of lignocellulose. Conf. FAO and Loc. Expert. Comm. Anim. Nutr., Mekerere Univ. Kampala, Uganda, FAO, Rome, 1971.

PONTES, M. Papel de la fibra en la alimentación de los ruminantes. Avance in Alimentacion $y$ Mejora Animal, 2ᄅㄷㄴ 10$): 411,1981$.

PUTNAM, P.A.; LEHMANN, R.; DAVIS, R.E. Feed intake and 
salivary secretion by steers. J. Anim. Sci. , Albany, $33(5): 1169,1971$.

RAUNS, N.S. \& BURROUGHS, $W$. Suction strainer technique in obtaining rumen fluid samples from intact lambs. I. Anim. Sci., Albany, 21(3):454-7, 1962.

RHODES, R. W. Influence of nutrient addition, physical form of the ration and interval of feeding on performance of 1ambs. Ames. 1961. CPhD - Thesis - Iowa State University of Science and Technologys.

ROFLER, R.E. \& SATTER, L.D. Relationship between ruminal ammonia and nonprotein nitrogen utilization by ruminants. 1. Development of a model for predicting non-protein nitrogen utilization by cattle. I. Dairy Sci., Champaign, 58(12): 1880-8, 1975.

RUMSEY, T.S.; PUTNAM, P.A.; BOND, J.; OLTJEN, R.R. Influence of level and type of diet on ruminal pH and VFA, respiratory rate and EKG patterns of steers. I. Anim. Sci. Albany, 3163):608-16, 1970.

SATTER, L.D. \& BAUMGARDT, B.R. Changes in digestive physiology of the bovine associated with various feeding frequencies. I. Anim. Sci., Albany, 21(4):897-900, 1962. 
SATTER, L.D. \& ROFFER, R.E. Nitrogen requeriment and utilization in dairy cattle. I. Dairy Sci. S8:1219, 1975 .

SATTER, L.D. \& SLYTER, L.L. Effect of ammonia concentration on rumen microbial protein production in vitro. Br. J. Nutr., Cambridge, 32(e): 199-208, 1974.

SCHAADT Jr., H. \& JOHNSON, R.R. VFA production in the rumen of sheep fed limestone and urea treated corn silage. I. Anim. Sci. , Albany, $\underline{\underline{2}}(5): 839-47,1969$.

SING, N. \&.SUD, S.C. Effect of different diets on pH and protein fractions in the rumen of buffaloes. Indian J. Dairy Sci. . New Delhi, 34(3): 284-7, 1981.

SINGH, S.P. \& GUPIA, B.N.' Effect of feeding ammoniated straw impregnated with urea and molasses on fibre digestibility and volatile fatty acids production rates in bufalloes. Indian J. Anim. Sci., New Delhi, 56(12): $1210-14,1986$.

SMITH, R.H. Digestion and metabolism in the ruminant. Armidale, Australia, I.W. MC Donald and A.C.I. Warner, eds. of New Engl and Press, 1975. 400p. 
STEWART, W.E.; STEWART, D. G.; SCHAULTZ, L.H. Rates of volatile fatty acid production in the bovine rumen. I. Anim, Sci. , Albany, 176 3):723-36, 1958.

VAN DER HORST, G.J.G. Keto acid and amines in the rumen 1iquor cattle. In: CHALUPA, W. Problems in feeding urea to ruminants. J. Anim. Sci. , Albany, 27(1): 207-19, 1968 .

VAN SOEST, P.J. Nutritional Ecology of the Ruminant. O \& $B$ Book, Inc., Corwallis, 1982. $374 \mathrm{p}$. 